\title{
場所打ち鉄筋コンクリート杭部材の 変形性能評価に関する研究
}

\author{
谷村幸裕 1 - 渡邊忠朋 2 - 瀧口将志 $3 \cdot$ 佐藤勉 4 \\ 1正会員 工修 （財）鉄道総合技術研究所（T185-8540 東京都国分寺市光町2-8-38） \\ 2正会員 北武コンサルタント（株）（テ062-0020 札幌市豊平区月寒中央通7丁目） \\ 3正会員 工修 九州旅客鉄道（株）（广807-0825 北九州市八幡西区折尾5丁目9-10）

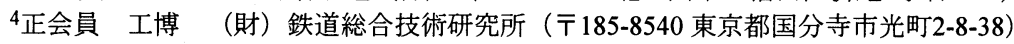

\begin{abstract}
兵庫県南部地震による鉄筋コンクリート構造物の被災を契機として，種々の機関で而震設計法の見直し がなされている，筆者らは，性能照査型設計体系への移行を念頭において，構造物の復旧性を照査する場 合に必要となる鉄筋コンクリート柱部材の損傷状況と修復のための補修方法を関連付けた損傷レベルを設 定し，その限界点を算定する手法を提案してきた。

本研究では，場所打ち鉄筋コンクリート杭部材の損傷レベル限界点の設定とその算定方法について，柱 部材の方法をもとに，断面形状，施工条件や軸方向力の違いを考慮して，その適用方法について提案をす るものである.
\end{abstract}

Key Words : cast-in-place concrete pile, evaluation of displacement ductility, damege degree, cyclic loading

\section{1. はじめに}

平成7年の兵庫県南部地震では, コンクリート構造物 に甚大な被害をもたらしたが，これを契機として，土木 学会をはじめ種々の機関で而震設計法に関する評価方法 の見直しがなされている(1),2).これに伴い, 従来に比べ て規模の大きい地震動に対する耐震性能を照査すること となり, 構造物には耐震性能の向上が求められている.

また，近年の耐震設計では，規模の大きい地震動に 対しては, 構造物の塑性化を許容するが, 塑性変形性能 を制御することで地震後の復旧性を含めて耐震性能を確 保することが一般的となっている．鉄道ラーメン高架橋 等の構造物においては, 柱部材が塑性化することが多い が, 柱部材については, 性能照査型設計体系への移行を 念頭において, 部材の損傷状況と補修工法を関連付けた 損傷レベル限界点を設定し，その限界点を算定する方法 が既に提案されている3).

しかしながら, 柱部材の耐力が構造物中の他の構成 部材に比べて相対的に高い場合は, 柱以外の部材等が塑 性化することも少なくない. 例えば, 杭基礎を有する高 架橋等の場合で, 柱部材等の上部構造が杭部材に比べて 耐力が高い場合, あるいは軟弱地盤上に構築される場合 等は, 杭部材の塑性化が避けられないことも多い.この
ような場合, 構造物全体の而震性能を合理的に評価する ためには，杭部材の塑性変形性能を適切に評価し，その 影響を考慮して解析を行うとともに, 杭部材の損傷状況 の評価が必要となってくる. 杭部材は円形断面を有して おり，矩形断面を有する柱部材を対象とした既往の損傷 レベル限界点の算定方法をそのまま用いることはできな いため, 円形断面を対象とした限界点の算定方法が必要 となる.

ところで, 近年都市部に建設される構造物の基礎杭 には，場所打ちコンクリート杭が用いられるのが一般的 となっている. 場所打ちコンクリート杭は, 施工性が良 好で低騒音で施工可能であり, かつ杭径や配筋の自由度 が高く, 大口径の杭も施工可能であるといった特徵を有 しており，杭基礎構造物に広く用いられている. しかし ながら, 場所打ちコンクリート杭に用いられるコンクリ 一トは，一般に，水中あるいは泥水中の施工となり，ま た，締め固めができないなど，通常のコンクリートの施 工とは大きく異なる. このようなコンクリートの施工条 件の違いは, 圧縮強度, ヤング係数やせん断強度に影響 を及ぼすことがすでに明らかにされている(1),5)。そこで, 場所打ちコンクリート杭の塑性変形性能を明らかにする ためには，このようなコンクリートの施工条件の違いを 考慮しておく必要があると考えられる. 
さらに，実構造物中の杭部材は地震の影響により大 きな軸力変動を生じる場合が多く, 一般的な鉄道構造物 でも, 釣合い軸力程度の大きな軸方向圧縮力や, 軸方向

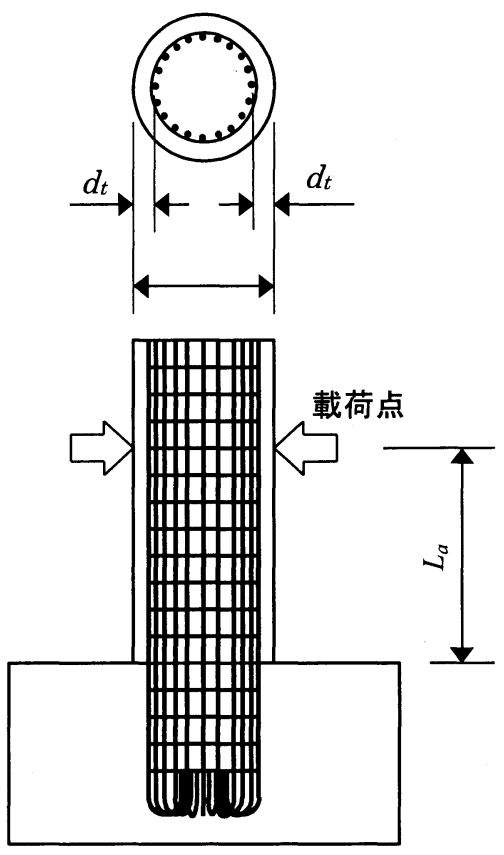

図-1 供試体の形状およひ配筋略図
引張力を生じる場合が少なくない，そのため，広い軸方 向力範囲に適用できる変形性能の評価方法が必要である.

場所打ち鉄筋コンクリート部材の変形性能について は, 既にいくつかの研究が行われているが(6) 9), 変形性 能の定量的評価や，復旧性を考慮した損傷との関連なら びに施工条件の影響については，十分明らかにされてい ないのが現状である．そこで，本研究では，部材を線材 としてモデル化した場合に, 構造物に想定される地震動 を作用させた動的解析から得られた応答より, 部材の損 傷状況を推定する方法を, 場所打ち鉄筋コンクリート杭 部材に適用するための検討を行うこととした. そのため に，場所打ち鉄筋コンクリート杭部材を模擬した供試体 を用いた交番載荷実験を実施し，実験結果をもとに，場 所打ち鉄筋コンクリート杭部材の非線形性と部材の損傷 状況の関連付けを行い，損傷状況を考慮した部材の変形 性能算定手法の提案を行うものである.

\section{2. 実験の概要}

\section{（1）供試体の形状および諸元}

実験に用いた供試体は，鉄道高架橋等の基礎に用い られる, 杭径 $1000 \mathrm{~mm}$ 程度の杭部材の $50 \sim 70 \%$ 縮小模型で ある．供試体の形状を図一 1 および表一 1 に示寸，供試 体の形状は，M-0，A-1〜4およびB-1〜 $5^{10)}, \mathrm{T}-1 \sim 3^{11), 12)}$

表-1 供試体の形状

\begin{tabular}{l|c|c|c|c|c}
\hline \multirow{2}{*}{ 供試体 } & \multirow{2}{*}{ 杭径 $R$} & \multirow{2}{*}{ スパン $L_{a}$} & \multicolumn{3}{|c}{ 軸方向鉄筋 } \\
\cline { 4 - 6 } & & & 呼び名一本数 & 芯かぶり $d_{t}$ & 軸方向鉄筋比 \\
\hline $\mathrm{M}-0$ & $500 \mathrm{~mm}$ & $1500 \mathrm{~mm}$ & D16-20本 & $78 \mathrm{~mm}$ & $2.02 \%$ \\
\hline $\mathrm{A}-1 \sim 4, \quad \mathrm{~B}-1 \sim 5$ & $500 \mathrm{~mm}$ & $1000 \mathrm{~mm}$ & D16-10本 & $58 \mathrm{~mm}$ & $1.01 \%$ \\
\hline $\mathrm{T}-1 \sim 3$ & $700 \mathrm{~mm}$ & $2100 \mathrm{~mm}$ & D22-20本 & $100 \mathrm{~mm}$ & $2.01 \%$ \\
\hline
\end{tabular}

表 -2 供試体の諸元

\begin{tabular}{|c|c|c|c|c|c|c|c|}
\hline \multirow{2}{*}{ 供試体 } & \multirow{2}{*}{$\begin{array}{l}\text { 施工 } \\
\text { 条件 }\end{array}$} & \multirow{2}{*}{$\begin{array}{c}\text { 帯鉄筋 } \\
\text { 呼び名@間隔(mm) }\end{array}$} & \multirow{2}{*}{$\begin{array}{c}\text { 帯鉄筋比 } \\
p_{w}(\%)\end{array}$} & \multirow{2}{*}{$\begin{array}{l}\text { 帯鉄筋の } \\
\text { 接合方法 }\end{array}$} & \multirow{2}{*}{$\begin{array}{l}\text { 軸圧縮応力度 } \\
\sigma_{0} \quad\left(\mathrm{~N} / \mathrm{mm}^{2}\right)\end{array}$} & \multicolumn{2}{|c|}{ コンクリート圧縮強度 $\left(\mathrm{N} / \mathrm{mm}^{2}\right)$} \\
\hline & & & & & & 杭体 $f_{c}^{\prime}$ & フーチング $f_{c t}^{\prime}$ \\
\hline $\mathrm{M}-0$ & 気中 & D10@75 & 0.38 & フレア溶接 & 2.70 & 31.4 & 31.3 \\
\hline A-1 & & \multirow{3}{*}{ D10@150 } & \multirow{3}{*}{0.19} & \multirow{9}{*}{$\begin{array}{c}\text { 端部に半円 } \\
\text { 形フックを } \\
\text { 取り付け, } \\
\text { 軸方向鉄筋 } \\
\text { に掛けて } \\
\quad \text { 定着 }\end{array}$} & 8.48 & 29.9 & 33.9 \\
\hline $\mathrm{A}-2$ & 水中 & & & & 8.03 & 35.6 & 32.1 \\
\hline A-3 & 泥水中 & & & & 8.65 & 31.7 & 34.6 \\
\hline $\mathrm{A}-4$ & 水中 & D10@75 & 0.38 & & 8.45 & 41.4 & 33.8 \\
\hline B-1 & 気中 & \multirow{3}{*}{ D10@150 } & \multirow{3}{*}{0.19} & & 0.00 & 35.3 & 29.3 \\
\hline B-2 & \multirow{3}{*}{ 水中 } & & & & 0.00 & 36.3 & 29.7 \\
\hline B-3 & & & & & 3.90 & 39.6 & 31.2 \\
\hline B-4 & & D10@75 & 0.38 & & 3.75 & 37.7 & 30.0 \\
\hline B-5 & 泥水中 & D10@150 & 0.19 & & 3.73 & 31.6 & 29.8 \\
\hline $\mathrm{T}-1$ & \multirow{3}{*}{ 気中 } & \multirow{3}{*}{ D16@125 } & \multirow{3}{*}{0.45} & \multirow{3}{*}{$\begin{array}{l}\text { フラッシュ } \\
\text { パット溶接 }\end{array}$} & 9.80 & 27.3 & 29.9 \\
\hline $\mathrm{T}-2$ & & & & & -3.82 & 27.7 & 31.8 \\
\hline $\mathrm{T}-3$ & & & & & $※$ & 23.2 & 28.1 \\
\hline
\end{tabular}

※: 変動軸力 (図 -3 参照) 
表一3 鉄筋の材料試験結果

\begin{tabular}{c|c|c|c}
\hline \multirow{2}{*}{ 供試体 } & 呼び名 & $\begin{array}{c}\text { 引張降伏強度 } \\
\left(\mathrm{N} / \mathrm{mm}^{2}\right)\end{array}$ & $\begin{array}{c}\text { ヤング係数 } \\
\left(\mathrm{kN} / \mathrm{mm}^{2}\right)\end{array}$ \\
\hline \multirow{2}{*}{$\mathrm{M}-0$} & $\mathrm{D} 16$ & 378 & 190 \\
\cline { 2 - 4 } & $\mathrm{D} 10$ & 367 & 187 \\
\hline \multirow{2}{*}{$\mathrm{A}-1 \sim 4$} & $\mathrm{D} 16$ & 376 & 190 \\
\cline { 2 - 4 } & $\mathrm{D} 10$ & 394 & 196 \\
\hline \multirow{2}{*}{$\mathrm{B}-1 \sim 5$} & $\mathrm{D} 16$ & 402 & 190 \\
\cline { 2 - 4 } & $\mathrm{D} 10$ & 394 & 196 \\
\hline \multirow{2}{*}{$\mathrm{T}-1 \sim 2$} & $\mathrm{D} 22$ & 401 & 190 \\
\cline { 2 - 4 } & $\mathrm{D} 16$ & 371 & 186 \\
\hline \multirow{2}{*}{$\mathrm{T}-3$} & $\mathrm{D} 22$ & 389 & 191 \\
\cline { 2 - 4 } & $\mathrm{D} 16$ & 389 & 185 \\
\hline
\end{tabular}

\begin{tabular}{|c|c|c|c|c|}
\hline 供試体 & $\begin{array}{c}\text { 呼ひ強度 } \\
\left(\mathrm{N} / \mathrm{mm}^{2}\right)\end{array}$ & $\begin{array}{c}\text { セメト } \\
\text { の } \\
\text { 種類 }\end{array}$ & $\begin{array}{c}\text { 粗骨材の } \\
\text { 最大寸法 } \\
(\mathrm{mm})\end{array}$ & $\begin{array}{l}\text { スランク } \\
(\mathrm{cm})\end{array}$ \\
\hline $\mathrm{M}-0$ & 21 & $\mathrm{H}$ & 20 & 12 \\
\hline $\begin{array}{l}\text { A-1 } \sim 4 \\
\text { B-1 } 1 \sim 5\end{array}$ & 27 & $\mathrm{~N}$ & 20 & 18 \\
\hline $\mathrm{T}-1 \sim 3$ & 18 & $\mathrm{H}$ & 20 & 18 \\
\hline
\end{tabular}

※ $\mathrm{H}$ : 早強ポルトランドセメント, $\mathrm{N}$ : 普通ポルトランドセメント

\begin{tabular}{|c|c|c|c|}
\hline 産地 & $\begin{array}{l}\text { 水分 } \\
(\%)\end{array}$ & $\begin{array}{c}\text { 土粒子密度 } \\
\left(\mathrm{g} / \mathrm{cm}^{2}\right)\end{array}$ & $\begin{array}{c}\text { PH } \\
(1 \% \text { sol })\end{array}$ \\
\hline 群馬県 & 8.4 & 2.4 & 9.8 \\
\hline
\end{tabular}

の3種類で，帯鉄筋比，軸圧縮応力度，施工条件等をパ ラメータとし，合計13体製作した.

供試体の諸元を表一 2 に，それぞれに使用した鉄筋 の材料試験結果を表一ろに，コンクリートの配合条件を 表一 4 に示寸，軸圧縮応力度については，鉄道高架橋等 の杭部材に作用する軸方向力を考慮して設定した.

また，コンクリートの圧縮強度は表一2に示したが， 施工条件が水中および泥水中の場合の杭体のコンクリー 卜強度 $f^{\prime}$ 'は，載荷試験終了後に杭先端部からコア抜き したテストピースの值を示し, 気中の場合については供 試体に用いたコンクリートを現場封縬養生したテストピ 一スの，載荷試験日の圧縮強度を示した。

\section{（2）施工条件}

場所打ち杭のコンクリートは, トレミ一管を用いて 水中あるいは泥水中で打設され，締め固めがされないな ど，通常のコンクリートと施工条件が大きく異なる. そ こで，本実験では表一2の施工条件に，水中および泥水 中と記した供試体（A-2〜4, B-2〜5) について, 実際の 場所打ち杭の施工を模擬してコンクリートの打設を行っ た.

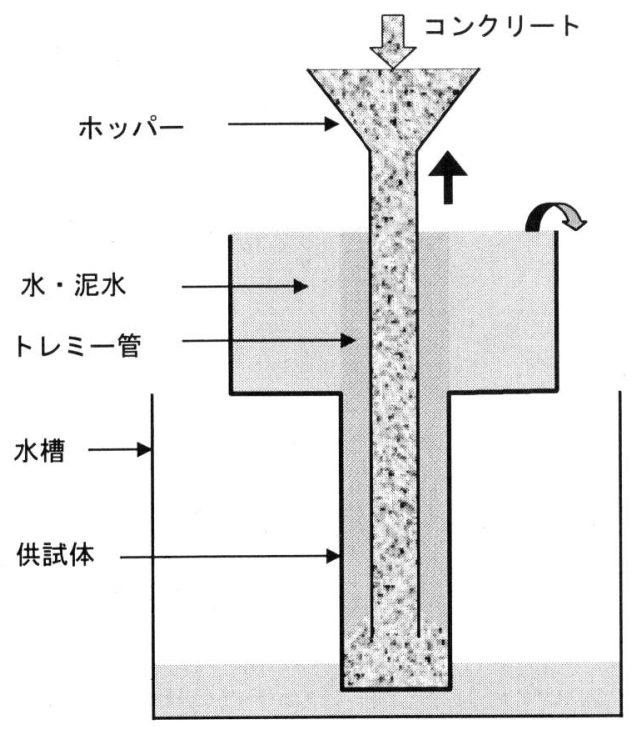

図－２コンクリート打設概要図

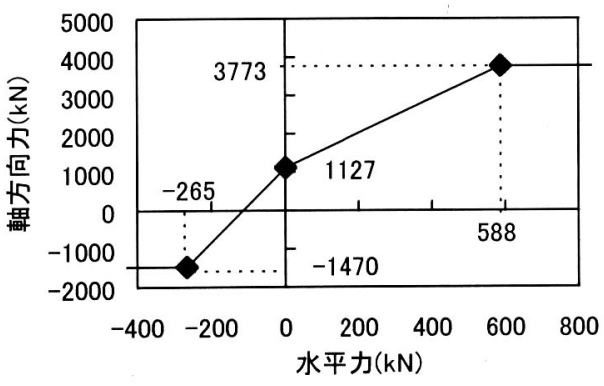

図ー3 軸力変動パターン（T-3）

これらの供試体製作の手順は，まずフーチングを上 にして型枠をセットし，杭体部の型枠内に水またはベン トナイト泥水を満たした。 なお，泥水中のベントナイト の濃度は $10 \%$ とし, ベントナイトの物理的性質は表一 5 に示寸。泥水にはCMCを $0.05 \%$ 添加し，ファンネル粘性 は24.2秒であった，そして，鉄筋籠を建て込んだ後，杭 体部のコンクリートを $\phi=200 \mathrm{~mm}$ のトレミ一管を用いて 打設した. コンクリートの締め固めは行っていない.コ ンクリートの打設概要図を図ー2に示寸，フーチングの コンクリートについては，通常どおり気中打設し，バイ ブレータを用いて締め固めを行った。

なお，表一2の施工条件で気中の場合は，杭体およ びフーチングともに通常のコンクリート打設を行い，気 中施工として締め固めを行った。打ち込み方向は, A-1 およびB-1はフーチングを上に，M-0およびT-1〜3はフー チングを下にしてコンクリートを打設した. 


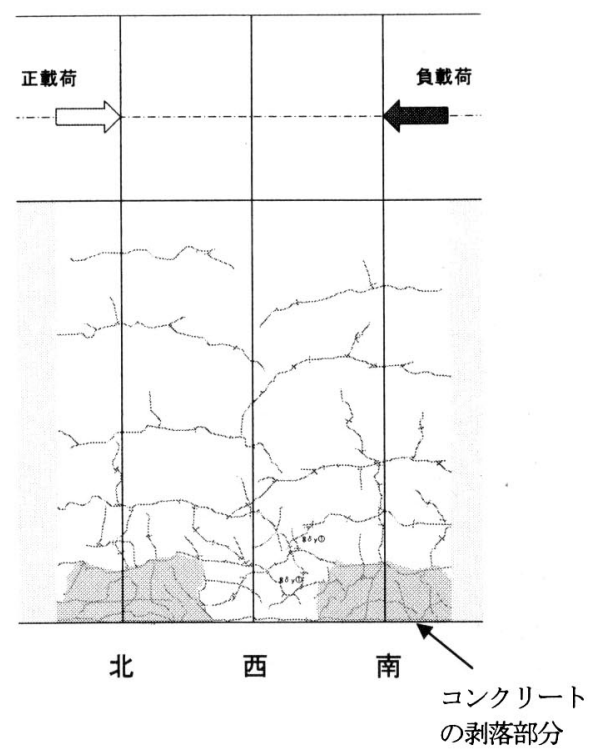

図ー4 載荷終了時のひひ割れ状況（M-0）

\section{（3）載荷方法}

載荷方法は, M-0, A-1〜4およびB-1〜 5については, 引張側最外縁の軸方向鉄筋が降伏したときの変位 $\delta_{y}$ を 基淮とし，その整数倍で正負交番載荷を行った．M-0は 各 $\delta_{y}$ で3回繰返し，A-1〜4およびB-1〜5は各 $\delta_{y}$ で2回繰 返しを行った. また, T-1〜3は部材角を基準とし，部材 角 $\theta=1 / 1000$ およ゙ $\theta=1 / 400$ で正負1回ずつの載荷を行っ た後， $\theta=1 / 200 ， 2200 ， 4 / 200 ， 6 / 200 ， 8 / 200,10 / 200$, 12200でそれぞれ3回ずつの正負交番載荷を行った。 なお， $\mathrm{T}-3$ は軸方向力を変動させて実験を行った. 軸力変動の パターンを図ー3に示す.ここで, 最大軸力および最小 軸力については，一般的な鉄道高架橋に地震時に生じる 軸力変動を考慮して設定し，部材が曲げ耐力に達したと きに最大軸力および最小軸力となるように水平力との関 係を設定した。

計測項目は，供試体の水平変位，鉛直変位，鉄筋の ひずみおよびひび割れ状況である.

\section{（4）破壊状況}

M-0の載荷終了時のひび割れ状況を図－4に，荷重一 変位関係を図一 5 (a) に示す. なお, 図一 5 (a) 〜 (c) の 水平荷重は, 偏心軸力による付加モーメントの影響を考 慮し, 測定された水平荷重に付加モーメントをスパンで 除した付加水平力を加算して補正したものである. まず, 杭部材基部に水平方向に曲げひひ割れが生じ，水平荷重 の増加とともに曲げひひ割れが発達していった. そして， 杭部材基部の引張側最外縁の軸方向鉄筋が降伏し（1 $\delta_{y}$ 写真一 1 (a))，その後水平変位の増加とともに順次軸 方向鉄筋が降伏し, かぶりコンクリートの圧壊が生じた

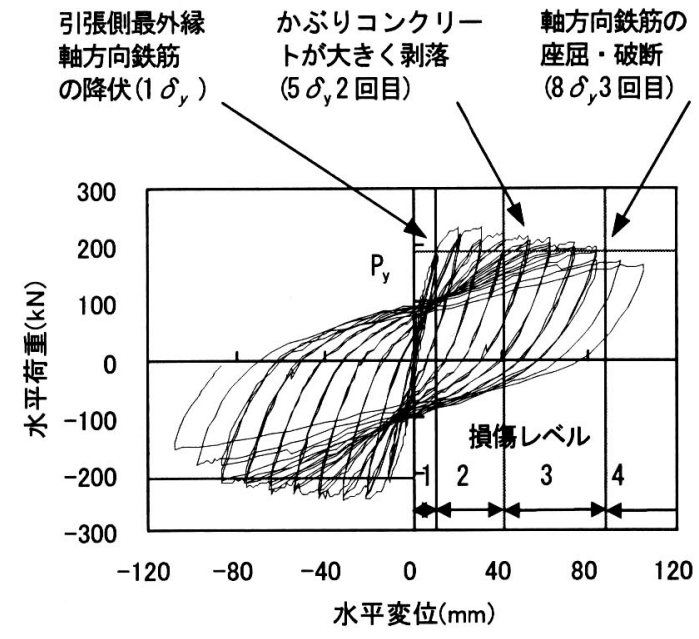

(a) M-0

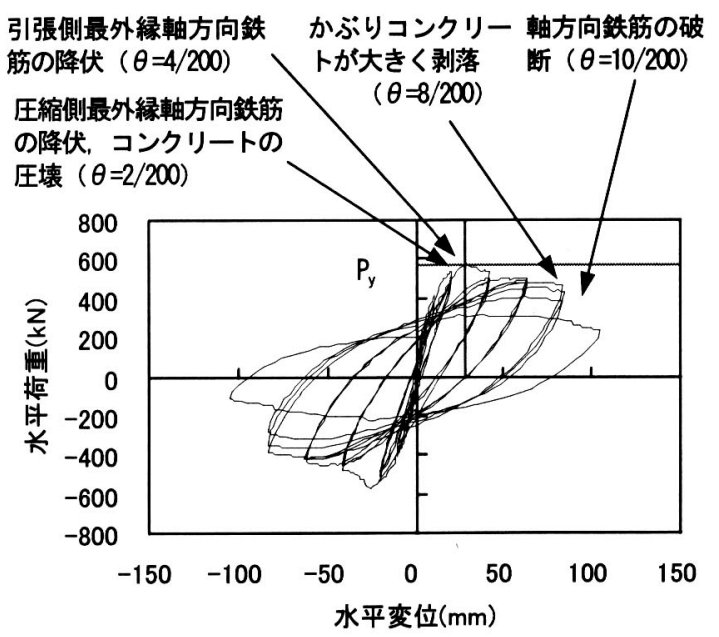

(b) $\mathrm{T}-1$

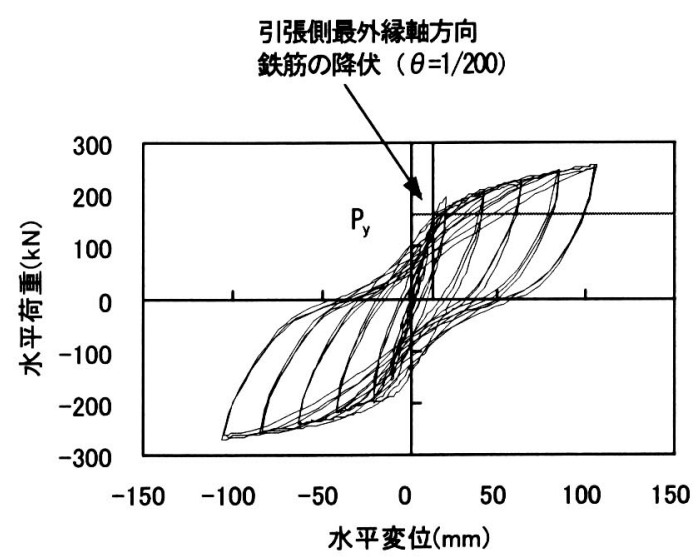

(c) $\mathrm{T}-2$

図－5 荷重一変位関係 


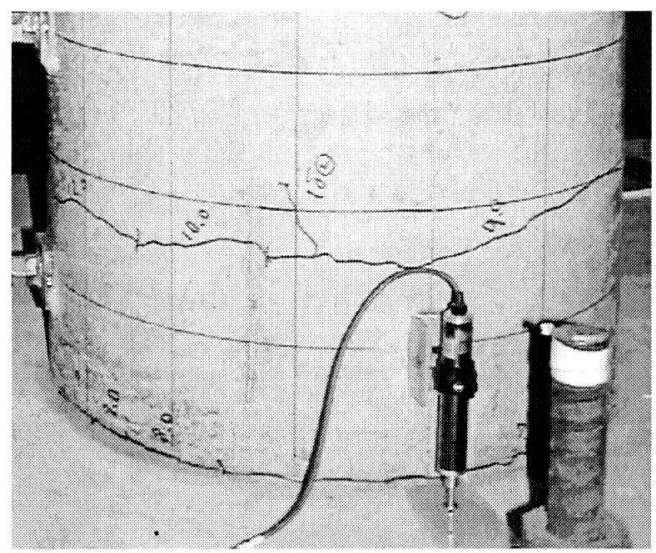

（a） $1 \delta_{y}$ 正載荷側 2 回目

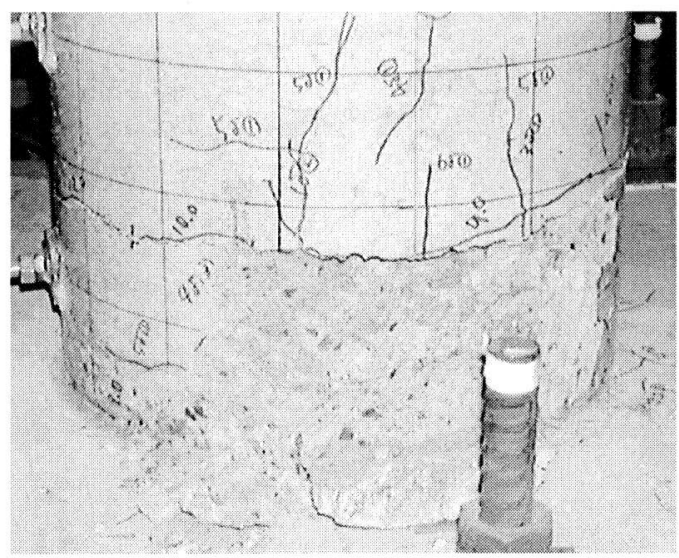

（c） $6 \delta_{y}$ 正載荷側 1 回目

写真-1 損傷状況 $(\mathrm{M}-0)$

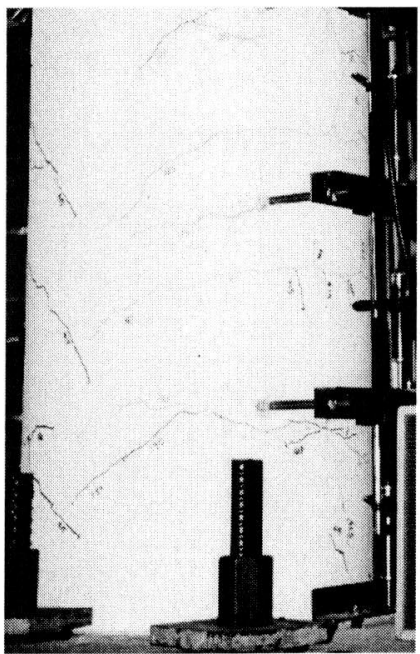

(a) $\theta=22200$ 正載荷側 3 回目

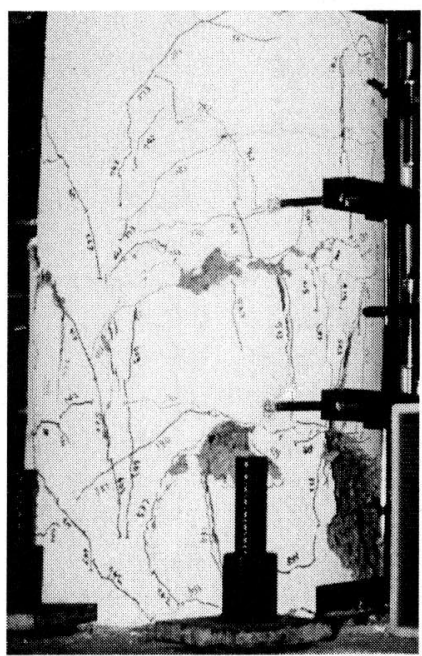

(b) $\theta=6 / 200$ 正載荷側 1 回目

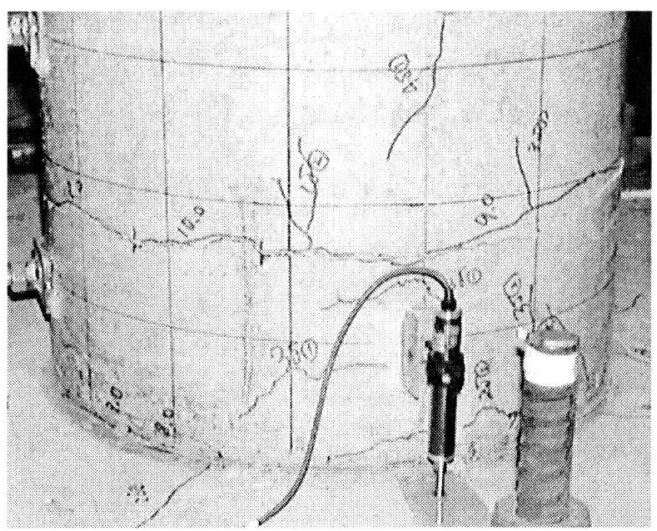

（b） $4 \delta_{y}$ 正載荷側 1 回目

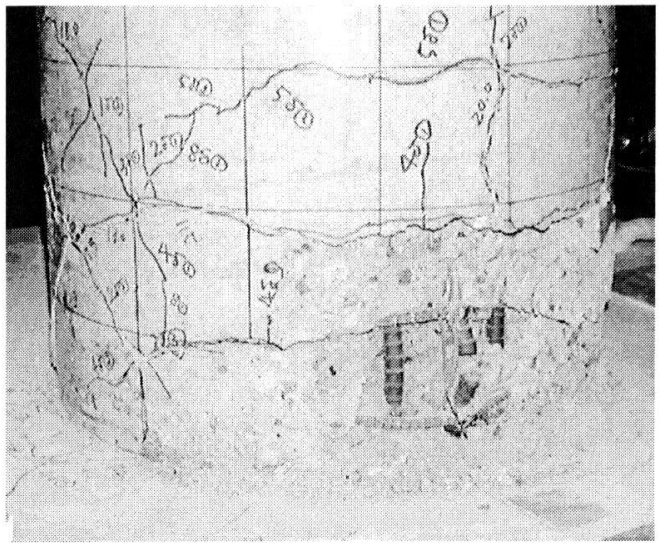

（d） $9 \delta_{y}$ 負載荷側 1 回目

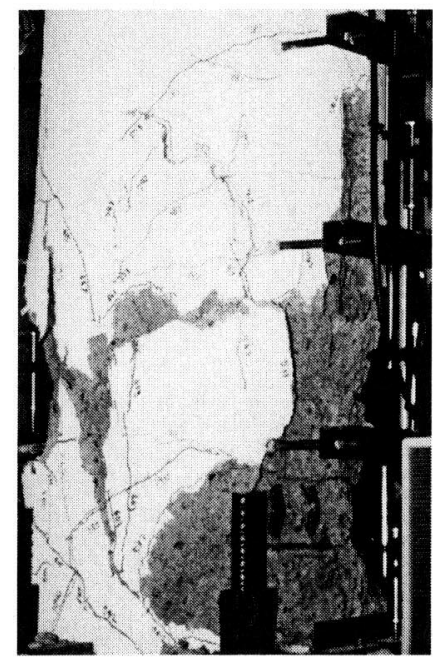

(c) $\theta=8 / 200$ 正載荷側 3 回目

写真－2 損傷状況（T-1） 


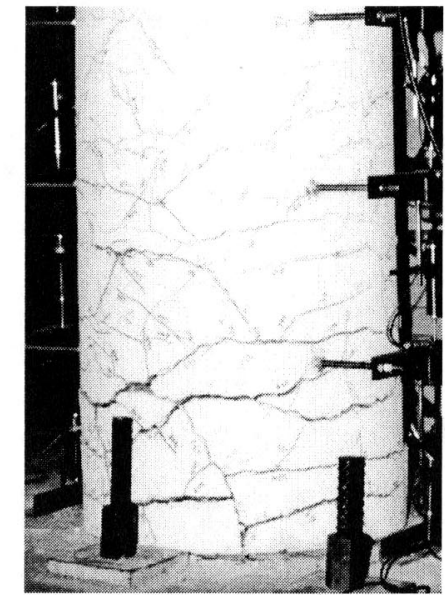

写真-3 載荷終了時の損傷状況（T-2）

(写真－1 (b))．さらに載荷を続けると， $5 \delta_{y}$ の2回目 の繰返し載荷でかぶりコンクリートが大きく剥落し（写 真－1 (c)），軸方向鉄筋が座屈し，軸方向鉄筋の破断 （8 $\delta_{y} 3$ 回目）に至った（写真一 1 (d)）。10 $\delta_{y}$ まで載荷 したが，水平荷重が降伏時の荷重を下回ったため実験を 終了した．以上の破壊状況より，曲げ破壊したものと考 えられる.

B-1〜5は，M-0とほぼ同様の破壊状況を呈しており， 曲げ破壊したものと考えられるが，軸方向鉄筋の破断に は至っていない.

T-1の荷重一変位関係を図ー 5 (b) に示す. T-1は軸方 向圧縮力が高く，釣合軸力に近い場合である。まず $\theta=2200$ で圧縮側最外縁の軸方向鉄筋が降伏し（写真一 2 (a)) , 続いて $\theta=4 / 2000$ 載荷途中で引張側最外縁の鉄 筋が降伏し，コンクリートの圧壊が観察された。その後 は，水平変位を増加しても水平荷重の上昇は殆ど見られ ず, コンクリートの圧壊が進展し（写真一2 (b)）， $\theta$
=8/200でがぶりコンクリートが大きく剥落するともに軸 方向鉄筋の座屈が生じて（写真－3 (c)），繰返し載荷 により水平荷重が大きく低下したため実験を終了した. したがって，曲げ圧縮破壊したものと考えられる.

A-1〜4は，T-1 と同様に比較的軸方向圧縮力の高い場 合であるが，水平荷重の増加に伴い，まず，圧縮側最外 縁の軸方向鉄筋が降伏し, 続いて引張側最外縁の鉄筋が 降伏した，その後，水平変位を増加しても水平荷重の上 昇は殆ど見られず，2 $\delta_{y}$ に至るまでにコンクリートが压 壊し，かぶりコンクリートの剥落を生じた，さらに載荷 在続けると，かぶりコンクリートが大きく剥落し，水平 荷重が低下したため，実験を終了した．いずれも曲げ圧 縮破壊したものと考えられる.

$\mathrm{T}-2$ の荷重一変位関係を図－5 (c) に示亦。T-2は，軸 方向引張力が作用する場合であり, 軸方向引張力の載荷 のみによってひび割れが生じている， $\theta=1 / 200 て ゙$ 最外縁 の軸方向鉄筋が引張降伏した．変位の増加に伴い，ひび 割れ幅とひひ割れ本数の増加が見られたが，コンクリー トの圧懐等の顕著な損傷は見られず，水平荷重が緩やか に増加していった（写真一3）. 載荷装置のストローク 容量の範囲では破壊に至らなかった。

T-3は軸方向力を変動した場合であるが，軸方向圧縮 力の作用する正載荷側はT-1と, 軸方向引張力の作用寸 る負載荷側はT-2と，それぞれ同様の破壊状況であった。

\section{3. 施工条件の影響}

（1）ひび割れ性状

図ー6に，A-1〜3の2 $\delta_{y}$ 載荷終了時におけるひび割れ 状況を示寸. 気中, 水中および泥水中施工の供試体とも に，曲げひび割れから発達した斜めひび割れの発生が観

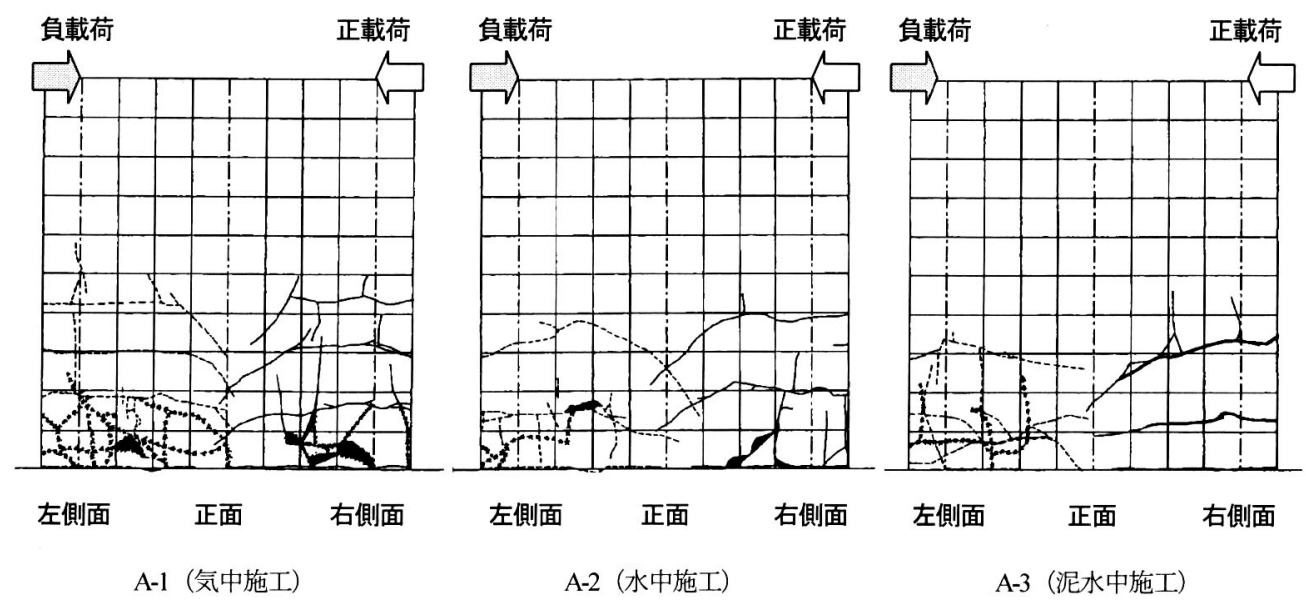

図一6ひひ割れ状況（A-1〜3，2 $\delta_{y}$ 時） 


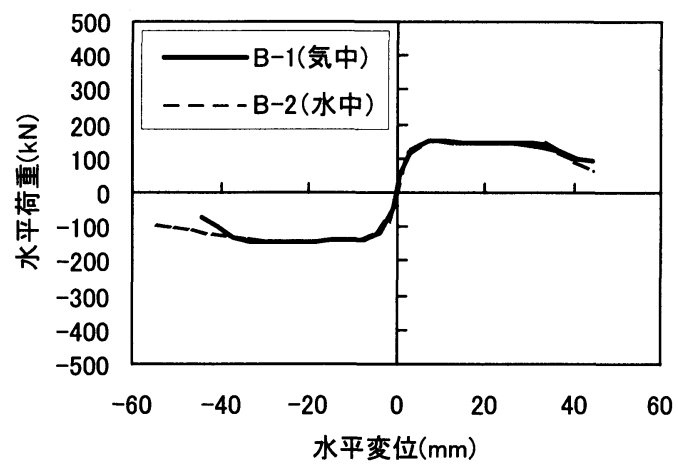

(a) 無軸力

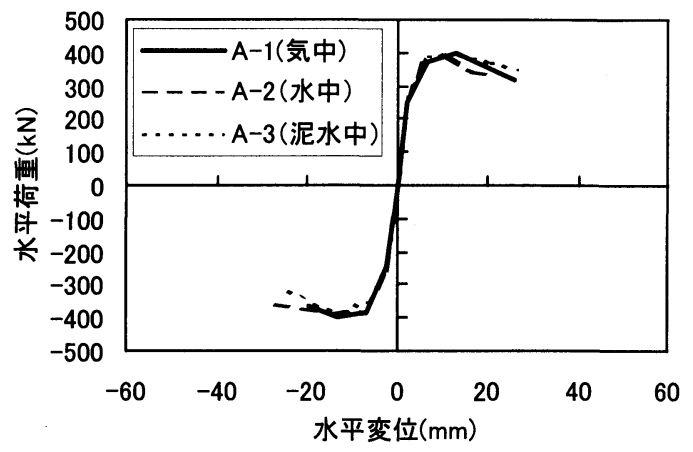

(b) 高軸力

図一7 荷重変位関係包絡線の施工条件による比較

察されている. また，水中施工(A-2)および泥水中施工 (A-3)の場合は，気中施工(A-1)に比べてひび割れが少なく なっている.これは，水中施工および泥水中施工では, 気中施工と比べてコンクリートの付着強度が低下してい るためではないかと考えられる.

\section{（2）荷重一変位関係}

荷重変位関倸の包絡線を，施工条件により比較した ものを図ー7に示す．同図(a)には軸方向力が作用しな い場合(B-1〜2)を，(b)には軸方向圧縮力が比較的高い場 合(A-1３)を示した. 図より，荷重変位関係の包絡線の 形状や終局変位には，施工条件による顕著な差は認めら れない結果となった．なお，軸方向圧縮力が高い場合は， 最大耐力は大きくなるが, 最大耐力に達した後に荷重低 下が始まる水平変位が小さくなる傾向が見られる.

\section{（3）軸方向鉄筋の抜出し}

施工条件が部材の変形に及ぼす影響を検討するため に，部材基部の軸方向鉄筋の抜出しによる回転変位に着 目して実験結果を整理した ${ }^{13)}$. A-1〜3の部材角（載荷点 の水平変位をスパンで除した值）と軸方向鉄筋の抜出し による基部回転角の関係を図一8に示す.

軸方向鉄筋の抜出しによる基部回転角は，次の $2 つ の ~$

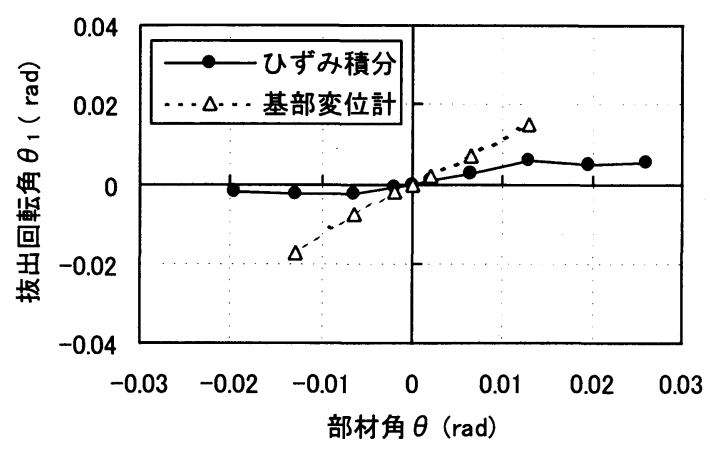

(a) A-1（気中施工）

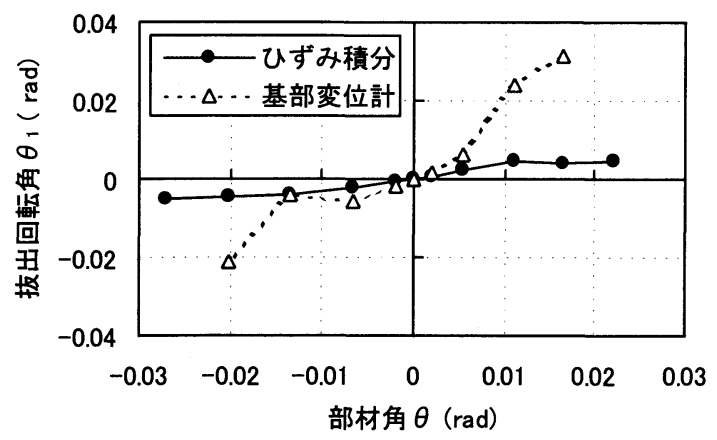

(b) A-2（水中施工）

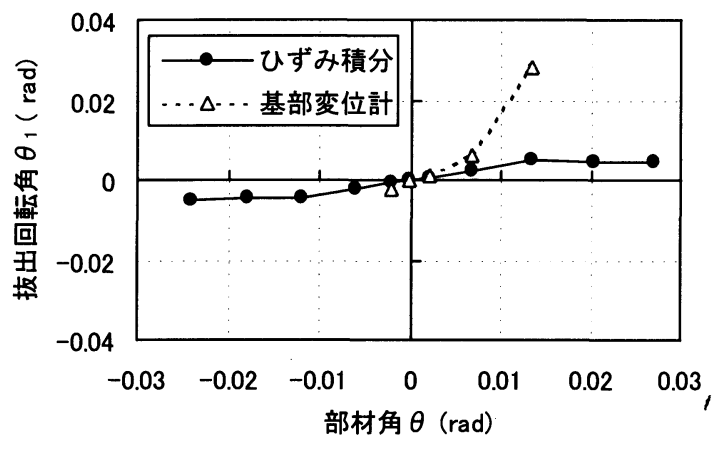

(c) A-3（泥水中施工）

図一8 部材角と軸方向鉄筋拔出しによる基部回転角の関倸

方法で算定した值を示した。一つは，最外縁の引張鉄筋 と圧縮鉄筋に，杭基部からフーチング内の深さ方向に $80 \mathrm{~mm}, 160 \mathrm{~mm}, 240 \mathrm{~mm}, 360 \mathrm{~mm}, 480 \mathrm{~mm}$ の箇所にひず みゲージを取り付け，計測值を積分して算定した引張鉄 筋と圧縮鉄筋の伸縮量の差を，鉄筋間の距離で除して求 めた回転角である．もう一つは，供試体基部の圧縮縁お よび引張縁において, 杭基部から $50 \mathrm{~mm}$ の高さのコンク リート表面より $50 \mathrm{~mm}$ 張り出した位置に変位計を設置し, 供試体基部とフーチングの相対変位を計測し，両者の差 を変位計間の距離で除して求めた回転角である. すなわ ち，前者は軸方向鉄筋のフーチング内からの抜出しであ り，後者は軸方向鉄筋のフーチング内からの抜出しのほ かに杭部材からの抜出しを含んだ值であると考えられる. 
ひずみ積分により算定した回転角は，A-1〜3で大きな 差が無く, フーチングからの軸方向鉄筋の抜出しによる 基部回転角には，大きな差異は無いことがわかる，一方， 基部変位計の測定值より算出された回転角は, 気中施工

（A-1）に比べて水中施工（A-2）および泥水中施工（A3）の方が大きな值を示しており，杭部材からの抜出し が大きくなる傾向が認められる.

これは，水中施工および泥水中施工の場合は，気中 施工に比べてコンクリートと鉄筋の付着強度が低下寸る ことによる影響と考えられる。

\section{4. 損傷レベルの評価}

\section{（1）RC杭部材の損傷レベル}

構造物の耐震性能を合理的に設定するためには，構 造物を構成する部材の損傷レベルを適切に設定する必要 がある. 本論文では， R C 杭部材の損傷レベルを，すで に提案されている R C 柱部材の損傷レベル゙)と同様な考 え方で設定することとした. すなわち，部材の変形と害 験で観察された損傷を関連付けることを前提に，主とし て部材の損傷状況と補修の難易性等の関係から，4つの レベルに区分することとし，それを損傷レベルと定義す ることとした．曲け破壊型となる場合の R C 部材の損傷 レベルと補修工法のイメージを表一6, 図一9に示す.

なお，杭部材は地中に存在するため, 柱部材に比べ て補修工事は困難になるものと考えられ，同じ補修工法 の場合でも補修の難易性は柱部材と異なる。これについ ては, 構造物の而震性能を照査する際に, 柱部材に比べ 杭部材の損傷レベルの制限を小さく設定することで考慮 することを考え, 損傷レベルの定義は, 部材の種類によ らず同様とすることとした.

\section{（2）損傷レベル 1}

損傷レベル 1 は，無損傷で無補修で済む段階とした. 一般に，軸方向鉄筇が降伏しなければ，地震後にひび割 れが閉じ，無補修でよいと考えられる. 杭部材の場合は, 円形断面であるため, 引張側最外縁の鉄筋が降伏しても， 荷重変位関係に直ちに変化が現われるわけではないが, 本論文では損傷レベル 1 の定義を安全側に適用すること を考え, 引張側最外縁の鉄筋が降伏するときを損傷レべ ル1の限界とすることとした.

\section{（3）損傷レベル 2}

損傷レベル 2 は, ひび割れ注入や断面修復が必要な 段階である. この段階での損傷は，コンクリートの圧壊 による剥落程度であり, 部材の耐荷性能が損なわれてお らず，早期修復が可能な状態である.
表一 $6 \mathrm{RC}$ 部材の損傷レベルと補修工法のイメージ

\begin{tabular}{|c|c|c|}
\hline 損傷レベル & 損傷状況 & 補修工法のイメージ \\
\hline $\begin{array}{c}1 \\
(0 \sim B)\end{array}$ & 無損傷 & 無補修 \\
\hline $\begin{array}{c}2 \\
(B \sim C)\end{array}$ & $\begin{array}{l}\text { 場合によっては } \\
\text { 補修が必要な損 } \\
\text { 傷 }\end{array}$ & 必要によりひび割れ注入 \\
\hline $\begin{array}{c}3 \\
(C \sim D)\end{array}$ & $\begin{array}{l}\text { 補修が必要な損 } \\
\text { 傷 }\end{array}$ & $\begin{array}{l}\text { ひび割れ注入，断面修 } \\
\text { 復，必要により带鉄筋の } \\
\text { 整正 }\end{array}$ \\
\hline $\begin{array}{c}4 \\
(D \sim)\end{array}$ & $\begin{array}{l}\text { 補修が必要で, } \\
\text { 場合によっては } \\
\text { 部材の取り替え } \\
\text { が必要な損傷 }\end{array}$ & $\begin{array}{l}\text { ひび割れ注入, 断面修 } \\
\text { 復, 带鉄筋の整正, } \\
\text { 軸方向鉄筋の座屈が著し } \\
\text { い場合は部材の取り替え }\end{array}$ \\
\hline
\end{tabular}

注：（）内に示す記号は図一 9 と対応している.

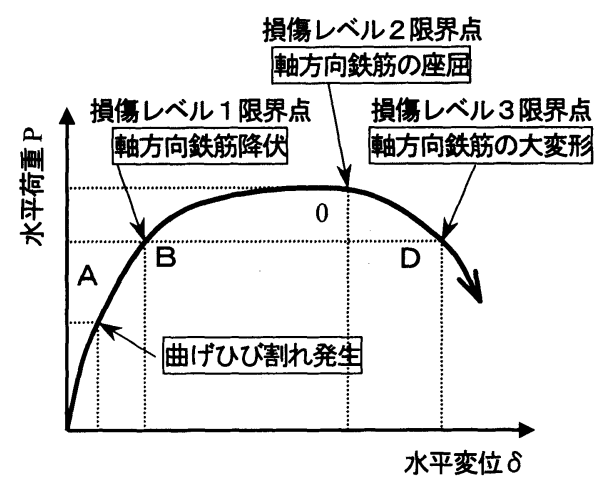

図-9 荷重一変位変化点での現象

実験からコンクリートの圧壊は, 最初は微小な剥落 程度であるが，ある変位を超えると，かぶりコンクリー トが大きく剥落する現象が観察されている. これは, 最 初はコンクリートの圧壊によりかぶりコンクリートが剥 落するが，ある変位を超えると，鉄筋の座屈によるかぶ りコンクリートの剥落が始まるためであると考えられる. このような損傷状況の変化は, 早期修復の可能性に関し て, 大きな差があると考えられる.

そこで，損傷レベル 2 の限界は，かぶりコンクリー トが大きく剥落しない最大変位とした.

\section{（4）損傷レベル3}

損傷レベル 3 は, 補修が必要な損傷で, ひび割れ注入 や断面修復, 場合によっては帯鉄筋等の整正が必要な段 階とした. この段階では, 部材の耐力が若干低下してい るものの, 補修により耐力を回復し, 部材を取り替える ことなく修復可能な状態である.

実験では, 荷重低下領域に入るとかぶりコンクリー トが大きく剥落し, 軸方向鉄筋の座屈が進展していった. 降伏荷重を維持できる範囲内では軸方向鉄筋の座屈は比 較的大きくないが，降伏荷重を下回るようになると軸方 
表-7 実験結果

\begin{tabular}{|c|c|c|c|c|c|c|c|c|c|c|}
\hline & \multicolumn{4}{|c|}{ 損傷レベル 1 限界点(降伏時) } & \multicolumn{4}{|c|}{ 損傷レベル 2 限界点 } & \multirow{2}{*}{\multicolumn{2}{|c|}{$\begin{array}{c}\text { 損傷レベル 3 限界点 } \\
\text { 変位 }(\mathrm{mm}) \\
\end{array}$}} \\
\hline & \multicolumn{2}{|c|}{ 荷重 $(\mathrm{kN})$} & \multicolumn{2}{|c|}{ 変位 $(\mathrm{mm})$} & \multicolumn{2}{|c|}{ 荷重 (kN) } & \multicolumn{2}{|c|}{ 変位 $(\mathrm{mm})$} & & \\
\hline & + & - & + & - & + & - & + & - & + & - \\
\hline $\mathrm{M}-0$ & 187 & -206 & 10.4 & -10.8 & 234 & -241 & 41.8 & 43.3 & 87.9 & -90.0 \\
\hline A-1 & 371 & -382 & 6.5 & -6.5 & 406 & -392 & $*_{1}$ & $* 1$ & $* 1$ & $* 1$ \\
\hline A-2 & 374 & -378 & 5.5 & -6.8 & 398 & -379 & $* 1$ & $* 1$ & $* 1$ & ${ }^{* 1}$ \\
\hline A-3 & 393 & -353 & 6.8 & -6.0 & 408 & -368 & $* 1$ & $* 1$ & $* 1$ & $* 1$ \\
\hline A-4 & 405 & -391 & 6.5 & -6.5 & 412 & -383 & $* 1$ & $* 1$ & ${ }^{* 1}$ & $* 1$ \\
\hline B-1 & 119 & -119 & 3.7 & -3.7 & 146 & -150 & 22.2 & -22.2 & 37.1 & -38.4 \\
\hline B-2 & 113 & -121 & 3.4 & -4.2 & 142 & -142 & 20.4 & -21.0 & 38.2 & -41.2 \\
\hline B-3 & 269 & -232 & 4.8 & -4.3 & 306 & -267 & 19.2 & $* 2$ & 32.4 & $* 2$ \\
\hline B-4 & 245 & -236 & 4.5 & -3.9 & 280 & -272 & 27.0 & -27.3 & 49.5 & -42.9 \\
\hline B-5 & 217 & -233 & 5.4 & -5.5 & 256 & -264 & 21.6 & -22.0 & 31.8 & -33.0 \\
\hline T-1 & 565 & -556 & 28.0 & -28.2 & 566 & -566 & $*_{1}$ & $* 1$ & $*_{1}$ & $* 1$ \\
\hline $\mathrm{T}-2$ & 163 & -154 & 13.8 & -10.0 & $* 3$ & $* 3$ & $* 3$ & $* 3$ & $* 3$ & $* 3$ \\
\hline T-3 & 590 & -205 & 19.2 & -12.4 & 616 & $* 3$ & $* 1$ & $* 3$ & $*_{1}$ & $* 3$ \\
\hline
\end{tabular}

*1 : 曲げ圧縮破壊, $* 2$ : 計測できず, *3 : 荷重低下に至らず

向鉄筋が大きく変形し，供試体によっては，軸方向鉄筋 の破断が生じ, 急激な耐力低下を生じるものもあった.

そこで，損傷レベル 3 限界は，降伏荷重を維持でき る最大変位とし, 損傷レベル 3 の限界点以上の変位の領 域は，損傷レベル 4 とした。

図ー 9 に，以上の損傷レベル限界点を，荷重一変位 関係包絡線上に模式的に示すとともに，実験から得られ た荷重一変位曲線上に，損傷レベルの限界点を示した例 を図一 5 (a)に示す.

\section{（5）実験結果}

表ー 7 に各供試体の, 各損傷レベル限界点の水平荷 重と水平変位を示す．なお，表一7の荷重は，偏心軸圧 縮力による付加モ一メントの影響を考慮し，測定された 水平荷重に付加モーメントをスパンで除した付加水平力 を加算して補正したものである.

なお，ここで定義した損傷レベルは，通常の曲げ破 壊型となる場合に適用するものであり，曲げ圧縮破壊と なる場合（A-1～4, T-1，T-3の正載荷側）には，そのま ま適用することはできない.これらについては，表－7 には損傷レベル 1 限界点の荷重および変位として引張鉄 筋降伏時の值を，損傷レベル 2 限界点の荷重として最大 荷重を記した。 なお，T-2ならびにT-3の負載荷側につい ては，実験の範囲で荷重低下に至っていない

\section{5. 変形性能の評価}

\section{（1）変形性能の評価}

部材の復旧性を考慮して耐震性能の照査を行うため
には，4．で示した各損傷レベルの限界点を算定する必 要がある. 本検討では, 耐震性能の照査をするための応 答值の算定に用いる構造解析に，部材を線材としてモデ ル化することを前提として，部材の非線形性を曲げ変形 解析によって算定する手法の検討を行うこととした．変 形性能の算定方法については，すでに提案されている柱 部材の変形性能算定方法 ${ }^{3}$ を基本として，断面形状が円 形であることなど杭部材特有の条件を考慮した変形性能 算定方法を検討することとした. 各損傷レベル限界点の 荷重および変形の算定手法を以下に示す.

なお，実験結果の検討については，3．より施工条 件によって軸方向鉄筋の抜出し量に差が見られたものの， 荷重変位関係の包絡線に大きな差が無かったことから, 施工条件の影響は特に考慮しないで検討することにする

\section{（2）損甥レベル 1 限界点}

損傷レベル 1 限界点は, 引張側最外縁の軸方向鉄筋 が引張降伏ひずみに達する点と定義される. 以下に，そ の算定方法を示す.

\section{a）荷重}

降伏荷重は，平面保持の仮定により算定する. なお, 以下の検討においては，コンクリートおよび鉄筋の応力 ひずみ関係は，土木学会コンクリート標準示方書・設計 編 ${ }^{14}$ に示されている，モデル化された応力ひずみ関係を 用いることとする. 図一10に降伏荷重の実験値と計算值 の比較を示す，図より，計算値はやや過小評価の傾向が あるが，実験値を概ね妥当に評価しているものと考えら れる.

b) 変位

損傷レベル1限界点（引張鉄筋降伏時）の変位 $\delta_{y}$ は, 


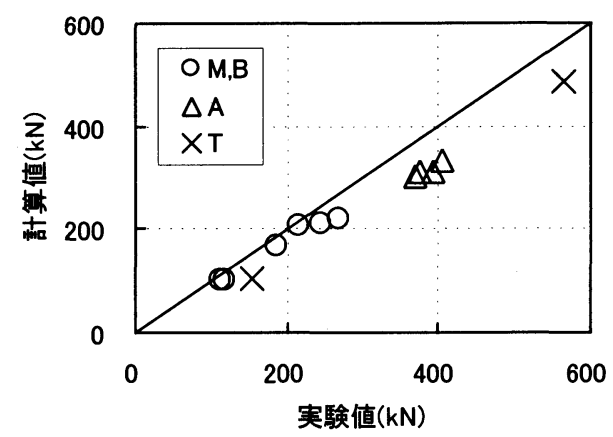

図-10 降伏荷重の実験值と計算値の比較
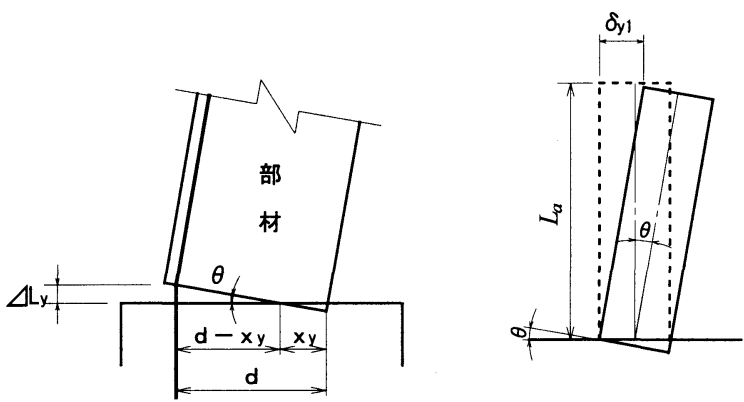

図ー12 フーチングからの鉄筋抜出しによる回転変位の算定
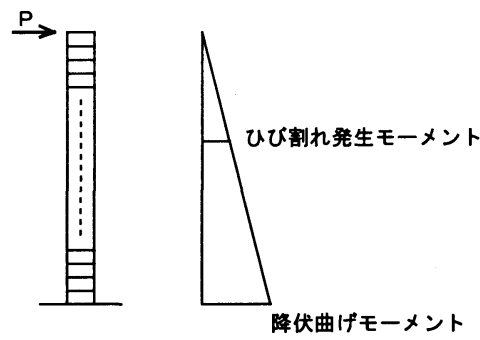

曲げモーメント分布

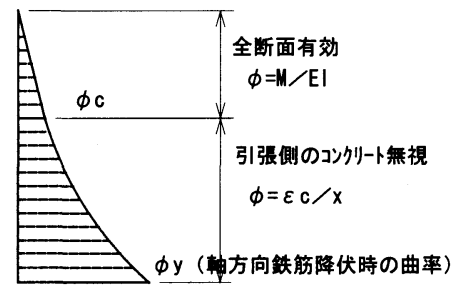

曲率分布

図-11 曲率積分による降伏時のく体変形量の算定（損傷レベル 1 )

く体の曲げ変形による変位 $\delta_{y 0}$ とフーチングからの軸方 向鉄筋の抜出しによる回転変位 $\delta_{y l}$ の和として算定する.

$$
\delta_{y}=\delta_{y o}+\delta_{y l}
$$

ここに, $\delta_{y}:$ 引張鉄筋降伏時の変位

$\delta_{y o}:$ 引張鉄筋降伏時のく体変形による変位で,

それぞれの断面の曲率を 2 階積分すること

により算定する. なお，曲げひひ割れが発

生していない断面の曲率は全断面有効と

して算定し，曲げひび割れが発生してい

る断面の曲率は引張側のコンクリートを

無視して曲率を算定する（図一11参照）.

$\delta_{y l}:$ 引張降伏時のフーチング内からの軸方向

鉄筋抜出しによる回転変位で，式(2)で算

定する（図-12参照）。

$$
\delta_{y l}=L_{a} \cdot \Delta L_{y} /\left(d-x_{\mathrm{y}}\right)
$$

ここに, $L_{a} \quad:$ せん断スパン

$\Delta L_{y}:$ 降伏時のフーチングからの引張鉄筋抜出

し量で, 式(3)で算定する ${ }^{15}$.

$$
\Delta L_{y}=7.4 \alpha \cdot \varepsilon_{y}\left(6+3500 \varepsilon_{y}\right) \phi /\left(f^{\prime}{ }_{c f}\right)^{2 / 3}
$$

ここに, $\varepsilon_{y}:$ 引張鉄筋の降伏ひずみ

$\phi:$ 引張鉄筋の直径 $f^{\prime}{ }_{c f}$ : フーチングのコンクリート圧縮強度 $\left(\mathrm{N} / \mathrm{mm}^{2}\right)$

$\alpha$ : 鉄筋間隔の影響を表す係数で, 式(4)で算 定する ${ }^{15}$.

$$
\alpha=1+0.9 e^{0.45(1-(D / \phi))}
$$

ここに, $D:$ 引張鉄筋の中心間隔

$d$ : 有効高さ

$$
d=R-d_{t}
$$

ここに, $R:$ 杭径

$d_{t}:$ 軸方向鉄筋の芯かぶり

$x_{y}$ : 降伏時の圧縮縁から中立軸の距離

図一13に降伏変位の実験值と計算值の関係を示す. A1〜4およびT-1の計算値は実験值をかなり過小に評価し ているが，これは，軸方向圧縮力が他に比べて大きく， 引張側鉄笳の降伏時には, 圧縮側コンクリートの圧壊が 生じているために，剛性が低下しているためと考えられ る. その他については, 計算値は実験值をやや過小評価 する傾向が見られるが，これは，荷重変位曲線上におい て, 降伏剛性の実験值と計算値は概ね一致していたこと より，降伏荷重計算値がやや過小評価となっている影響 と考えられる. 
（3）損傷レベル2限界点

損傷レベル 2 限界点は，軸方向鉄筋の座屈により， かぶりコンクリートが大きく剥落しない最大変位と定義 した.

なお，曲げ圧縮破壊となった A-1〜4およびT-1ならび にT-3の正載荷側については，以下の検討からは除外す る. また, 軸方向引張力が作用しているT-2ならびにT-3 の負載荷側については, 実験の範囲では荷重の低下が見 られなかったため, 以下の検討からは除外する.これら の検討から除外した試験体については，6. で変形性能 の評価方法について検討をする.

したがって，以下の検討はM-0およびB-1〜5を対象に 行い, 正載荷側と負載荷側の損傷レベル 2 限界点には顕 著な差が見られなかったため, 以下の検討は正載荷側の みに着目して行った.

\section{a) 荷重}

コンクリートの最外縁圧縮ひずみが $\varepsilon^{\prime}=0.0035$ となる ときの荷重（曲げ耐力 $M_{m}$ に相当する）とする.

図一14に, 水平荷重の実験値と計算値の関係を示す. ここで, 水平荷重の実験值は, 偏心軸力による付加モー メントの影響を考慮し, 測定された水平荷重に付加モー メントをスパンで除した付加水平力を加算して補正した ものである. なお，図中にはA-1〜5およびT-1〜3の最大 荷重の実験値と計算値の関係もあわせて示した. やや, 過小評価の傾向は見られるものの, 概ね妥当に評価して いるものと考えられる結果となった.

b) 変位

損傷レベル 2 限界点の変位 $\delta_{m}$ は, く体の曲げ変形に よる変位 $\delta_{m 0}$ と, フーチングからの軸方向鉄筋の抜出し による回転変位 $\delta_{m l}$ の和として算定する. ここで, く体 の曲け変形による変位 $\delta_{m o}$ は, さらに塑性ヒンジ部の曲 げ変形による変位 $\delta_{m p}$ と塑性ヒンジ部以外の曲げ変形に よる変位 $\delta_{m b}$ に分けて算定する（図一15，16参照）.

$$
\delta_{m}=\delta_{m 0}+\delta_{m l}=\delta_{m b}+\delta_{m p}+\delta_{m l}
$$

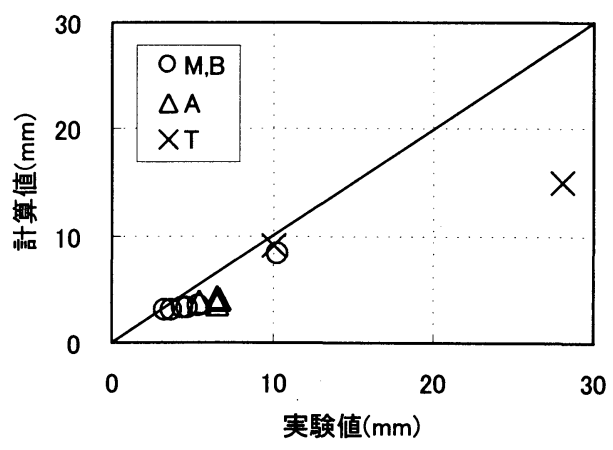

図-13 降伏変位の実験值と計算値の比較

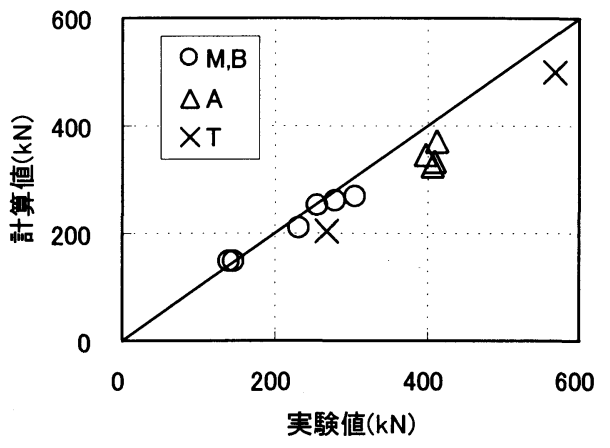

図-14 損傷レベル 2 限界荷重の実験值と計算值の比較

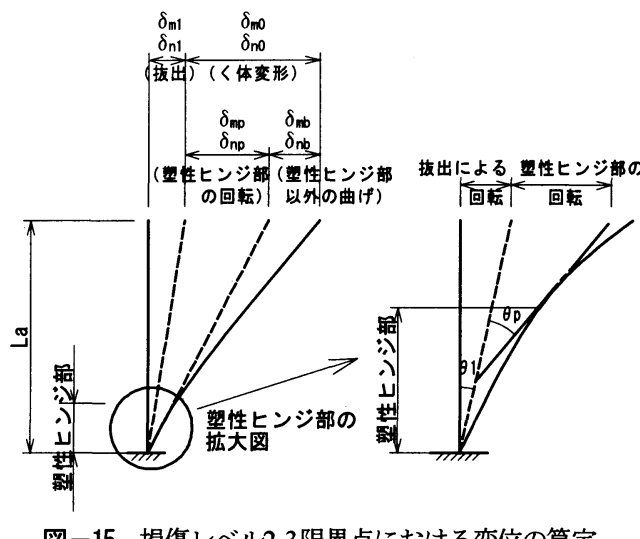

図ー15 損傷レベル2,3限界点における変位の算定
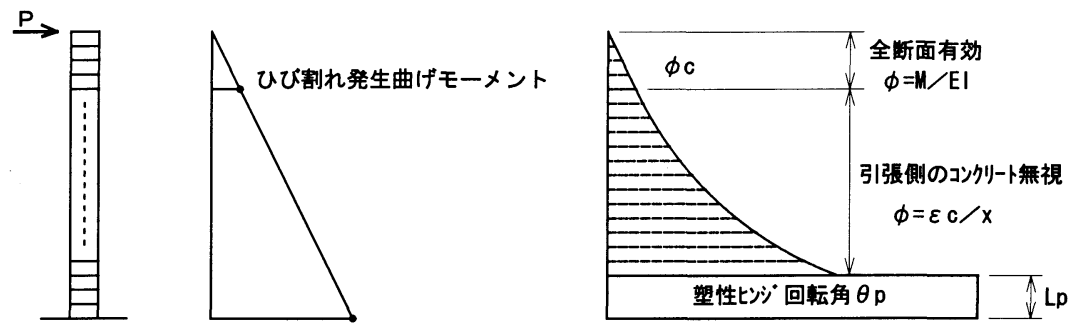

損傷レベル2(最大曲げモーメント) 損㑥レベル3(降伏曲げモーメント)

曲げモーメント分布

曲率分布

図ー16 曲率積分によるく体変形量の算定（損傷レベル 2 および 3 ） 
ここに, $\delta_{m}:$ 損傷レベル 2 限界点の変位

$\delta_{m 0}:$ 損傷レベル 2 限界点のく体変形による変 位 $\left(=\delta_{m b}+\delta_{m p}\right)$

$\delta_{m b}:$ 損傷レベル 2 限界点のく体変形のうち, 塑性ヒンジ部以外の曲げ変形による変位. 部材を材軸方向に分割し，それぞれの断 面の曲率を積分することにより算定する (図一16参照)．

$\delta_{m p}:$ 損傷レベル 2 限界点のく体変形のうち, 塑性ヒンジ部の曲げ変形による変位

$\delta_{m l}:$ 損傷レベル 2 限界点のフーチング内から の軸方向鉄筋の抜出しによる回転変位

本モデルにおいては，塑性ヒンジ部の曲げ変形による 変位 $\delta_{m p}$ を, 塑性ヒンジ回転角 $\theta_{p m}$ と等価塑性ヒンジ長 $L_{p}$ を用い，回転中心を塑性ヒンジ中心とすることにより 式(7)で算定することとした．また，塑性ヒンジ長算定 式として，Mattockらによる式(8) ${ }^{16}$ 用いることとした.

$$
\delta_{m p}=\theta_{p m} \cdot\left(L_{a}-L_{p} / 2\right)
$$

ここに, $\theta_{p m}:$ 損傷レベル 2 限界点の塑性ヒンジ回転角

$L_{a}:$ せん断スパン

$L_{p}:$ 等価塑性ヒンジ長

$$
L_{p}=0.5 d+0.05 L_{a}
$$

ここに, $d:$ 断面の有効高さ

\section{c）鉄筋抜出しによる回転変位}

損傷レベル 2 限界点のフーチング内からの軸方向鉄筋 の抜出しによる回転変位 $\delta_{m l}$ は, 柱部材の場合 ${ }^{3)}$ 之同様 に，式(9)で算定することとした.

$$
\delta_{m l}=\left\{\left(2.7 k_{w l} \cdot p_{w}+0.22\right)\left(1-N / N_{b}\right)+1\right\} \delta_{y l}
$$

ただし, $2.7 k_{w 1} \cdot p_{w}+0.22 \leqq 3.7$

ここに, $N / N_{b}$ ：釣合軸力比で，Nは作用軸力， $N_{b}$ は釣合 軸力．釣合軸力 $N_{\mathrm{b}}$ は，引張鉄笳が降伏 すると同時にコンクリートの圧縮ひず みが終局ひずみ（ $\varepsilon^{\prime}{ }^{\prime}=0.0035 ）$ に達する ときの軸力とした.

$p_{w} \quad:$ 帯鉄筋比(\%)

$k_{w 1} \quad:$ 帯鉄筋の強度を考慮する俰数

$$
k_{w l}=f_{w y} / 390
$$

ここに, $f_{w y}:$ 帯鉄筋の引張降伏強度 $\left(\mathrm{N} / \mathrm{mm}^{2}\right)$

\section{d）塑性ヒンジ回転角}

柱部材の $\theta_{p m}$ は, 式(12)で表される゙).

$$
\theta_{p m}=\left(0.021 k_{w 0} \cdot p_{w}+0.013\right) /\left(0.79 p_{t}+0.153\right)
$$

ただし, $0.021 k_{w 0} \cdot p_{w}+0.013 \leqq 0.04$
$0.79 p_{t}+0.153 \geqq 0.78$

ここに, $p_{w}:$ 帯鉄笳比(\%)

$p_{t}:$ 引張鉄筋比 $(\%)$

$k_{w 0}:$ 帯鉄筋の強度を考慮する係数

$$
k_{w 0}=f_{w y} / 390
$$

ここに, $f_{w y}:$ 帯鉄筋の引張降伏強度 $\left(\mathrm{N} / \mathrm{mm}^{2}\right)$

ところで，式(9)および式(12)を，杭部材に適用するに

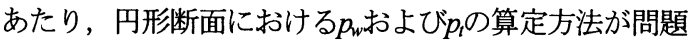
となる. 本検討では， $p_{w}$ を式(16)で算定することとした。

$$
p_{w}=100 \cdot A_{w} /\left(R \cdot s_{s}\right)
$$

ここに, $A_{w}:$ 区間 $s_{s}$ における帯鉄筋の総断面積

$R:$ 杭径

$s_{s}:$ 帯鉄筋の配置間隔

また, $p_{i}$ については, 場所打ち杭部材の場合は施工に よる制約から，柱部材に比べて軸方向鉄筋比が小さくな る傾向があるが，本実験で用いた断面を面積の等しい正 方形に換算して求めると, $p_{t}=0.3 \sim 0.6 \%$ 程度となり, 式 (14)の範囲を外れることになる. そこで本検討では， $p_{t}$ は式(14)の下限値をとるものと考え, 塑性ヒンジ回転角 を式(17)で算定することとした.

$$
\theta_{p m}=\left(0.0021 k_{w 0} \cdot p_{w}+0.013\right) / 0.78
$$

\section{e) 実験値と計算値の比較}

図ー17に，損傷レベル 2 限界点の変位 $\delta_{m}$ の実験值 $\left(\delta_{\text {mexp }}\right)$ と計算値 $\left(\delta_{\text {mcal }}\right)$ の関係を示す. 提案式は 実験值を妥当に評価しているものと考えられる。

\section{（4）損傷レベル 3 限界点}

損傷レベル 3 限界点は, 降伏荷重程度の水平抵抗を 維持する最大変位と定義される. なお, 正載荷側と負載 荷側の損傷レベル限界点では, 若干差異があるものの概 ね等しいと判断し, 本検討では正載荷側のみに着目して 行った.

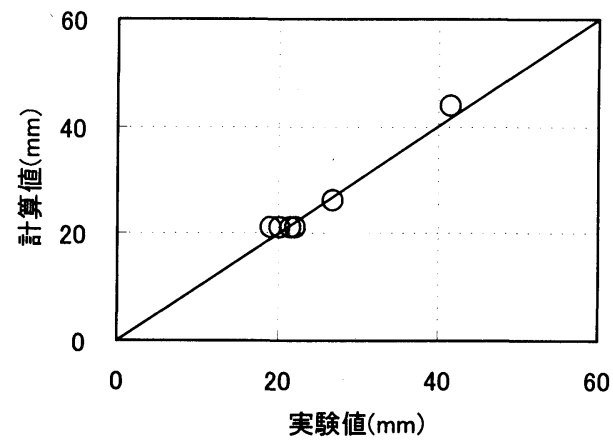

図-17 損傷レベル 2 限界変位の実験值と計算値の比較 


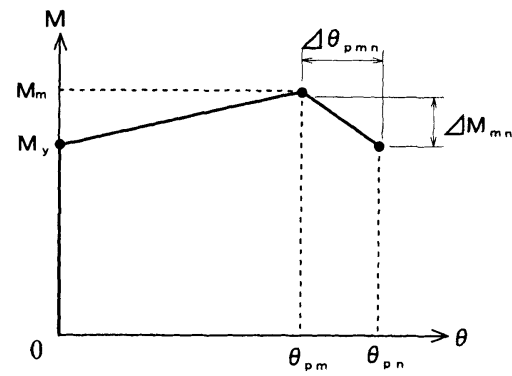

図ー18 モデル化した曲げモーメントと塑性ヒン ジ回転角の関係

\section{a) 荷重}

定義より，降伏荷重となる.

\section{b) 変位}

損傷レベル 3 限界点の変位 $\delta_{n}$ は, 損傷レベル 2 限界 点と同様に, く体の曲げ変形による変位 $\delta_{n 0}$ とフーチン グからの軸方向鉄筋の抜出しによる回転変位 $\delta_{n 1}$ の和と して算定する. ここで, く体の曲げ変形による変位 $\delta_{n 0}$ は, さらに塑性ヒンジ部の曲げ変形による変位 $\delta_{n p}$ と塑 性ヒンジ部以外の曲げ変形による変位 $\delta_{n b}$ に分けて算定 する(図一15参照)。

$$
\delta_{n}=\delta_{n 0}+\delta_{n l}=\delta_{n b}+\delta_{n p}+\delta_{n l}
$$

ここに， $\delta_{n}$ : 損傷レベル 3 限界点の変位

$\delta_{n 0}:$ 損傷レベル 3 限界点のく体変形による変 位 $\left(=\delta_{r b}+\delta_{r p}\right)$

$\delta_{n b} \quad$ : 損傷レベル 3 限界点のく体変形のうち塑 性ヒンジ以外の曲げ変形による変位. 部 材を軸方向に分割しそれぞれの断面の曲 率を 2 階積分することにより算定する.

$\delta_{n p}:$ 損傷レベル 3 限界点のく体変形のうち, 塑性ヒンジ部の曲げ変形による変位

$\delta_{n 1} \quad$ : 損傷レベル 3 限界点のフーチング内から の軸方向鉄筋抜出による回転変位

\section{c）塑性ヒンジ部以外の曲げ变形}

塑性ヒンジ部以外の曲げ変形による変位 $\delta_{m b}$ は, 降伏 時と同様に曲率の 2 階積分により算定する（図一 15 参 照）。なお, 荷重一変位関係において耐力低下域にある ため，本来は除荷の影響を考慮する必要があるが，塑性 ヒンジ部以外の曲げ変形が全体変位に占める割合は小さ

く, 簡単のために除荷の影響は無視することとした.

\section{d）鉄筋抜出しによる回転変位}

損傷レベル 3 限界点の鉄筋抜出しによる回転変位 $\delta_{n l}$ は, 柱部材の場合と同様 ${ }^{3}$, 損傷レベル 2 限界点以降は 変化しないと仮定し，次式で算定することとした.

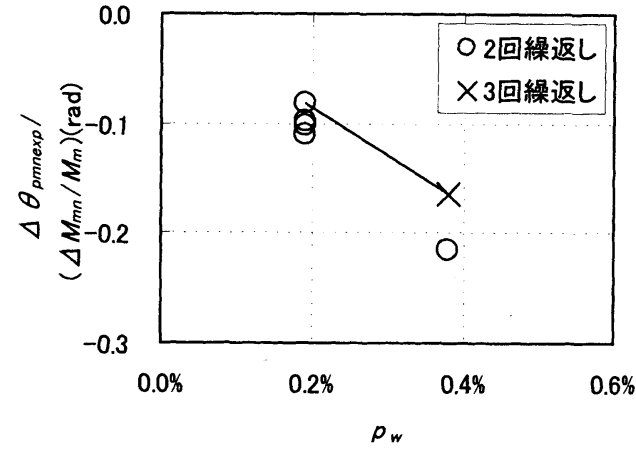

図-19 損傷レベル 2 限界点〜 3 限界点無次元曲げモーメ ントー塑性ヒンジ回転角負勾配と帯鉄筋比の関倸

$$
\begin{gathered}
\delta_{n I}=\theta_{n I} \cdot L_{a} \\
\theta_{n l}=\theta_{m l}
\end{gathered}
$$

ここに， $\delta_{n I}$ : 損傷レベル 3 限界点のフーチング内から の軸方向鉄筋抜出しによる回転変位

$\theta_{n 1}:$ 損傷レベル 3 限界点のフーチング内からの 軸方向鉄筋抜出しによる回転角

$\theta_{m l}:$ 損傷レベル 2 限界点のフーチング内からの 軸方向鉄筋抜出しによる回転角

\section{e）塑性ヒンジ回転角}

塑性ヒンジ部の曲げ変形 $\delta_{n p}$ は, 損傷レベル 2 限界点 と同様に塑性ヒンジ回転角 $\theta_{p n}$ と等価塑性ヒンジ長 $L_{p}$ を 用い次式で算定する.

$$
\delta_{n p}=\theta_{p n} \cdot\left(L_{a}-L_{p} / 2\right)
$$

ここに, $\theta_{p n}$ : 損傷レベル 3 限界点の塑性ヒンジ回転角

$L_{p}:$ 等価塑性ヒンジ長で, 式(8)で算定する

損傷レベル 3 限界点の塑性ヒンジ回転角 $\theta_{p n}$ は, 式 (22)に示すように，損傷レベル 2 限界点の塑性ヒンジ回 転角 $\theta_{p m}$ と, 損傷レベル 2 限界点から損傷レベル 3 限界 点までの塑性ヒンジ回転角増分 $\Delta \theta_{p m n}$ の和として算定 することとした。（図-18参照)

図-19 に損傷レベル 2 限界点から損傷レベル 3 限界 点の塑性ヒンジ回転角增分の実験值 $\Delta \theta_{\text {pmnexp }}$ と, 曲げ モーメントの减少分 $\Delta M_{m n}\left(=M_{y}-M_{m}\right)$ を $M_{m}$ て除して 無次元化したもの $\left(\Delta M_{m n} / M_{m}\right)$ との比と, 帯鉄筋比 $p_{w}$ の関係を示す．なお，ここで用いた塑性ヒンジ回転角 増分の実験值 $\Delta \theta_{\text {pmnexp }}$ は, 実験から得られた $\delta_{\text {nexp }}$ か ら前述の方法で算定した $\delta_{n b}, \delta_{n 1}$ および $\delta_{m p}$ を差し引 いた変位量を $\left(L_{a}-L_{p} / 2\right)$ で除した值である。

図一19より，帯鉄筋比 $p_{w}$ が大きくなると，負勾配 $\Delta \theta_{\text {pmnexp }} /\left(\Delta M_{m n} / M_{n}\right)$ が小さくなっており，すな わち耐力低下が緩やかになっていることがわかる，柱部 
表－8 損傷レベル限界点の実験値と計算値の関係

\begin{tabular}{|c|c|c|c|c|c|c|c|c|c|c|}
\hline & \multicolumn{4}{|c|}{ 損傷レベル 1 限界点(降伏時) } & \multicolumn{4}{|c|}{ 損傷レベル 2 限界点 } & \multirow{2}{*}{\multicolumn{2}{|c|}{$\begin{array}{c}\text { 損傷レベル } 3 \text { 限界点 } \\
\text { 変位 }(\mathrm{mm})\end{array}$}} \\
\hline & \multicolumn{2}{|c|}{ 荷重 $(\mathrm{kN})$} & \multicolumn{2}{|c|}{ 変位 $(\mathrm{mm})$} & \multicolumn{2}{|c|}{ 荷重 $(\mathrm{kN})$} & \multicolumn{2}{|c|}{ 変位 $(\mathrm{mm})$} & & \\
\hline & 実験値 & 計算值 & 実験値 & 計算値 & 実験値 & 計算值 & 実験值 & 計算值 & 実験値 & 計算値 \\
\hline $\mathrm{M}-0$ & 187 & 167 & 10.4 & 8.3 & 234 & 208 & 41.8 & 43.8 & 87.9 & 84.1 \\
\hline B-1 & 119 & 103 & 3.7 & 3.0 & 146 & 147 & 22.2 & 21.0 & 37.1 & 40.5 \\
\hline B-2 & 113 & 103 & 3.4 & 2.9 & 142 & 147 & 20.4 & 20.9 & 38.2 & 40.5 \\
\hline B-3 & 269 & 218 & 4.8 & 3.1 & 306 & 266 & 19.2 & 20.9 & 32.4 & 32.8 \\
\hline B-4 & 245 & 212 & 4.5 & 3.2 & 280 & 260 & 27.0 & 25.9 & 49.5 & 49.8 \\
\hline B-5 & 217 & 205 & 5.4 & 3.3 & 256 & 248 & 21.6 & 21.0 & 31.8 & 32.3 \\
\hline 平均値 & \multicolumn{2}{|c|}{1.14} & \multicolumn{2}{|c|}{1.38} & \multicolumn{2}{|c|}{1.06} & \multicolumn{2}{|c|}{1.00} & \multicolumn{2}{|c|}{0.98} \\
\hline 変動係数 & \multicolumn{2}{|c|}{$5.3 \%$} & \multicolumn{2}{|c|}{$13.6 \%$} & \multicolumn{2}{|c|}{$6.8 \%$} & \multicolumn{2}{|c|}{$5.6 \%$} & \multicolumn{2}{|c|}{$4.5 \%$} \\
\hline
\end{tabular}

※ 平均値 : 実験值 $/$ 計算值

材は帯鉄筋比によらず負勾配は一定値となっており ${ }^{3)}$, 杭部材は柱部材の場合と異なる傾向となっている。これ は, 柱部材の場合は矩形断面であるため, 圧縮側に配置 された軸方向鉄筋はある変形量で一斉に座屈を開始する のに対し, 杭部材の場合は円形断面であるため, 最外縁 の軸方向鉄筋から徐々に座屈を始めることの違いによる ものと考えられる. すなわち, 軸方向鉄筋が座屈を始め る変形量は帯鉄筋比 $p_{w}$ の影響を受けるが, 座屈開始後 の水平変位の増加による座屈の進展は帯鉄筋比 $p_{w}$ との 関係が小さいと考えられる.このため, 矩形断面では, 損傷レベル 2 限界点を超えると圧縮側の軸方向鉄筋はす でに座屈しており，負勾配は帯鉄筋比 $p_{w}$ の影響をあま り受けないが, 円形断面の場合は, 損傷レベル 2 限界点 以降も, 最外縁鉄筋の座屈後に側方の軸方向鉄筋が順に 座屈を始めるため, 負勾配が帯鉄筋比 $p_{w}$ の影響を受け るものと考えられる.

また, 本実験では, 各 $\delta_{y}$ で 3 回繰返しを行った場合 （M-0）と 2 回繰返しを行った場合（B-1～5）が混在し ているが, 図一19 より繰返し回数が多い方が耐力低下 が大きくなる結果となっている. 柱部材の場合にも損傷 レベル 2 限界点以降の荷重一変位関係において, 繰返し 回数の影響が顕著になることが明らかにされており ${ }^{17}$, 杭部材の場合も同様に繰返し回数の影響を受けているも のと考えられる.

塑性ヒンジ回転角増分 $\Delta \theta_{p m n}$ の定式化にあたっては, 帯鉄筋比 $p_{w}$ と負勾配 $\Delta \theta_{p m n e x p} /\left(\Delta M_{m n} / M_{n}\right)$ の関 係を図一19 に実線で示すように，3回繰返しのデータ と原点を結ぶ直線関係として表現することとし, 式(23) により算定することとした.

$$
\begin{gathered}
\theta_{p n}=\theta_{p m}+\Delta \theta_{p m n} \\
\Delta \theta_{p m n}=0.4 p_{w}\left(M_{m}-M_{y}\right) / M_{m}
\end{gathered}
$$

ここに, $\theta_{p n}$ : 損傷レベル 3 限界点の塑性ヒンジ回転角

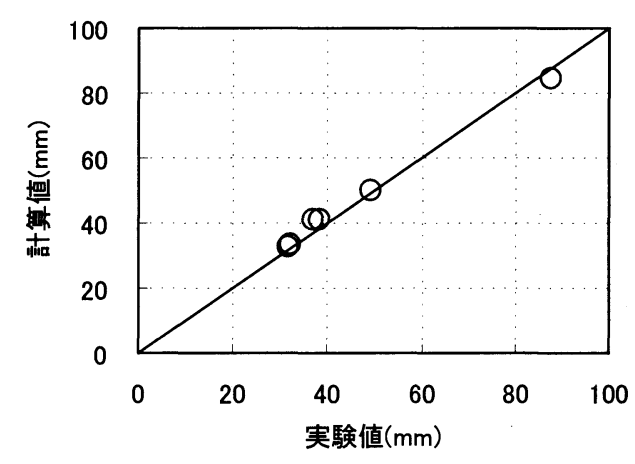

図-20 損傷レベル 3 限界変位の実験值と計算值の比較

$\Delta \theta_{p m n}:$ 損傷レベル2 限界点〜損傷レベル 3 限 界点の塑性ヒンジ回転角増分

$M_{m}:$ 最大曲げモーメント

$M_{y} \quad$ : 降伏曲げモーメント

なお，本実験で用いた降伏変位 $\delta_{y}$ を基準とした載荷 方法では, 軸力により $\delta_{y}$ の值が変化するため, 同じ $1 \delta_{y}$ ごとの繰り返し回数であっても，同一変位までの累 積繰り返し回数は軸力により異なることになるが，本論 文ではこの影響を無視している.

\section{f）実験値と計算値の比較}

図一20に損傷レベル 3 限界点の変位 $\delta_{n}$ の実験値と計 算值の比較を示す．提案式は，実験值を概ね安全側に評 価しているものと考えられる.

\section{（5）各損傷レベル限界点の実験値と計算値の比較}

以上の算定方法から得られた各損傷レベル限界点の 計算值と，M-0およびB-1 5の実験值との比較を表 -8 に示す. なお，表一8には各実験値と計算値の比の平均 值および変動倸数を示した. 各損傷レベル限界点に対し て，概ね精度よく算定できる結果となっている. 


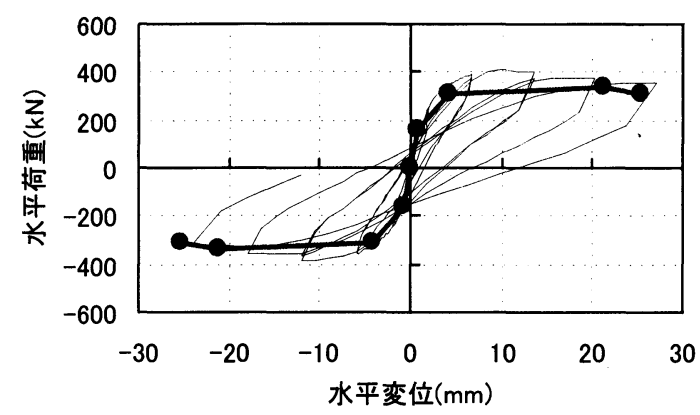

(a) A-3

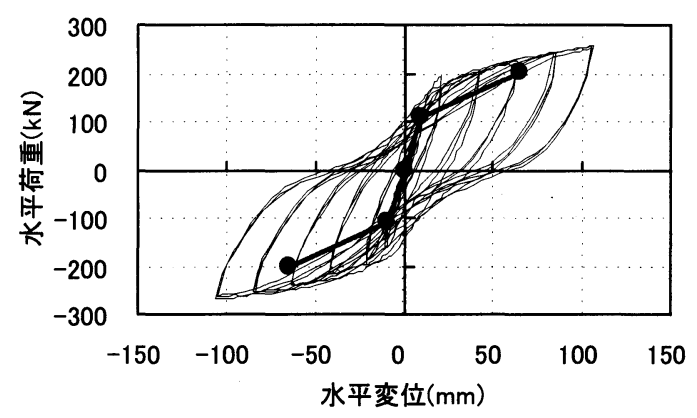

(c) T-2

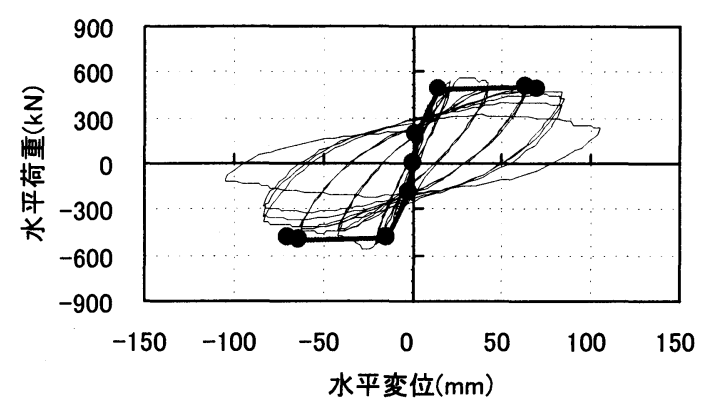

(b) $\mathrm{T}-1$

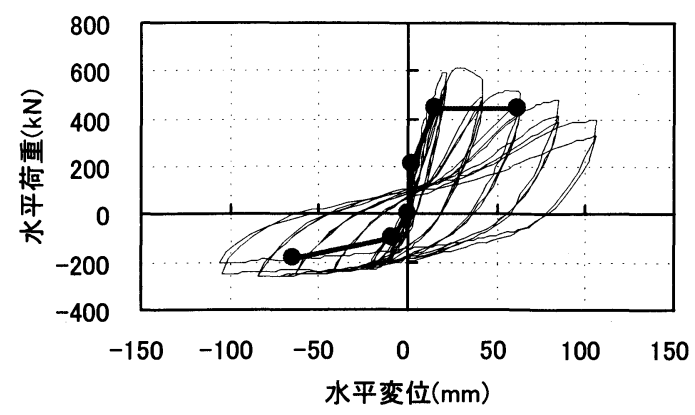

(d) $\mathrm{T}-3$

図-21 荷重一変位関係と損傷レベル限界点の計算值

\section{6. 軸方向力の影響}

\section{（1）軸方向力の適用範囲}

鉄道高架橋等に用いられる杭部材は，地震の影響に より大きな軸力変動を生じ, 釣合い軸力付近の高い軸方 向圧縮力や軸方向引張力を生じることが多い. そこで, 本モデルをこのような場合に適用した場合の, 軸方向力 の影響について検討することとする.

図一21に示したA-3，T-1～3の荷重変位関係に, 本論 文で提案した算定方法による算定結果をプロットし各損 傷レベル限界点を太線で結んで示した. なお，図には各 損傷レベル限界点に加えて, 曲げひひ割れ発生点もプロ ットして太線を結んである. なお, 曲げひひ割れ発生点 の荷重は，コンクリートの縁引張応力度が部材寸法の影 響を考慮したコンクリートの曲げ強度 ${ }^{18)}$ に達するときの 荷重, 変位は, 部材の全断面を有効として求めた.

\section{（2）高軸方向圧縮力が作用する場合}

A-3は軸方向圧縮応力度が $8.65 \mathrm{~N} / \mathrm{mm}^{2}, \mathrm{~T}-1$ は $9.80 \mathrm{~N} / \mathrm{mm}^{2}$ と高い軸方向圧縮力が作用しており, 釣合軸力に近い場 合である. 図一21 (a)，(b)より，損傷レベル 1 限界点は 荷重, 変位とも計算値は実験值をやや過小に評価する結 果となっているが, 降伏点に至るまでの剛性はほぼ一致 している. また，損傷レベル 2 限界点ならびに損傷レベ
ル 3 限界点は, 荷重, 変位とも実験値をほぼ妥当に評価 している.

図一5(b)に，T-1の荷重変位関係に損傷状況を併せて 示したが, 部材角 $\theta=8 / 200$ でかぶりコンクリートが大き く剥落し軸方向鉄筋の座屈が進展した. 実験の損傷状況 からは, その手前の $\theta=6 / 200 か ゙$ 損傷レベル 2 限界点と考 えられる. また, 鉄筋の座屈は $\theta=8 / 2000$ 繰返しで急激 に進展しており，この付近を損傷レベル 3 限界点とする ことができる. 荷重一変位関係からは, 降伏後まもなく 最大耐力に達した後, すぐに降伏荷重を下回ってしまう ため，4．の定義では損傷レベル 3 限界点は計算值より もはるかに小さい值となる．しかしながら，降伏荷重を 下回った後も直ちに急激に荷重が低下するわけではなく， 損傷状況からも $\theta=6 / 200 \sim 8 / 200$ 付近を損傷レベル 3 限界 点とするのが妥当と考えられることから, 計算值は損傷 レベル限界点をほぼ妥当に評価できているものと考えら れる.

\section{（3）軸方向引張力が作用する場合}

T- 2 は，軸方向引張力が作用する場合である．図一 21 (c)には，実験の範囲では水平荷重が低下しなかった ため，損傷レベル 2 限界点までの計算値を示した. 図よ り各損傷レベル限界点とも，計算值は実験值を安全側に 評価している. 
実験では, 損傷レベル 2 限界变位の計算値以降も水 平荷重は増加を続けており, 目立った損傷の進展も見ら れなかった. 図には示していないが，損傷レベル 3 限界 点水平荷重の計算値（=降伏荷重）は, 実験値を大きく 過小評価する結果となった．また，実験では曲げ耐力の 計算値よりもかなり大きい水平荷重が生じているが，こ れは，鉄筋のひずみ硬化の影響によるものと思われる.

実験での部材の損傷状況は，曲げひび割れが拡大す る以外に目立った損傷はなく，4．で定義した損傷レべ ル 3 以降の損傷状況の変化は観察されなかった. このた め, 軸方向引張力が卓越する場合は, 損傷レベル 3 限界 点を設ける必要がないと考えられる.

なお，実構造物の杭部材においては，T-2のように軸 方向引張力が常に一定で作用することはなく，T-3のよ うに軸方向力が変動して作用することになる. また，軸 力変動で軸方向引張力が作用する場合は，他方の杭は高 軸方向圧縮力が作用することになる．同じ変形量であれ ば，高軸方向圧縮力を受ける場合のほうが顕著な損傷を 受けており, 構造物全体では, 而震性能は高軸方向圧縮 力を受ける場合で決定されることになる. したがって, 軸方向引張力を受ける杭部材に本論文のモデルを適用し ても，構造物の耐震性能を評価するうえで差し支えない ものと考えられる.

\section{（4）変動軸力が作用する場合}

$\mathrm{T}-3$ は変動軸力が作用する場合である．なお，T-3の正 載荷側は，釣合軸力を超える軸方向力が作用しており， 損傷レベル限界点は，釣合軸力以下の場合との連続性を 考慮し, 次のようにして求めた.

\section{a）損傷レベル 1 限界点}

まず, 荷重は, コンクリートの最外縁圧縮ひずみが $\varepsilon^{\prime}{ }^{\prime}=0.0035$ となるときの荷重とする.

また，変位は，コンクリートの最外縁圧縮ひずみが

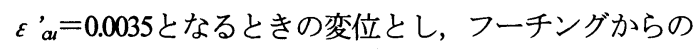
軸方向鉄筋の抜出しを考慮し, 次式により算定する.

$$
\delta_{c u}=\delta_{c u o}+\delta_{c u l}
$$

ここに, $\delta_{c u}$ : コンクリートの最外縁圧縮ひずみが $\varepsilon^{\prime}{ }_{a u}=0.0035$ となるときの変位

$\delta_{\text {cuo }}$ : コンクリートの最外縁圧縮ひずみが $\varepsilon_{a u}^{\prime}=0.0035$ となるときのく体変形による 変位で, それぞれの断面を 2 階積分する ことにより算定する．なお，曲げひび割 れが発生していない断面の曲率は全断面 有効として算定し, 曲げひび割れが発生 している断面の曲率は引張側のコンクリ 一トを無視して曲率を算定する.

$\delta_{c u l}:$ 引張鉄筋降伏時のフーチング内からの軸
方向鉄筋抜出しによる回転変位で, 式 (25)で算定する.

$$
\delta_{c u l}=L_{a} \cdot \Delta L_{c u} /\left(d-x_{c u}\right)
$$

ここに, $L_{a} \quad$ : せん断スパン

$\Delta L_{c u}$ : コンクリートの最外縁圧縮ひずみが $\varepsilon^{\prime}{ }^{\prime}=0.0035$ となるときのフーチングから の引張鉄筋抜出し量で, 式(26)で算定する. $d$ : 有効高さ

$\mathrm{x}_{\mathrm{cu}} \quad$ : コンクリートの最外縁圧縮ひずみが $\varepsilon^{\prime}{ }_{a}^{\prime}=0.0035$ となるときの圧縮縁から中 立軸の距離

$$
\Delta L_{y}=7.4 \alpha \cdot \varepsilon_{s c u}\left(6+3500 \varepsilon_{s c u}\right) \phi /\left(f^{\prime}{ }_{c f}\right)^{2 / 3}
$$

ここに, $\varepsilon_{s c u}$ : コンクリートの最外縁圧縮ひずみが $\varepsilon^{\prime}{ }_{a u}=0.0035$ となるときの引張鉄筋のひ ずみ

$\phi:$ 引張鉄筋の直径

$f^{\prime}{ }_{c f}$ : フーチングのコンクリート压縮強度 $\left(\mathrm{N} / \mathrm{mm}^{2}\right)$

$\alpha$ : 鉄筋間隔の影響を表す係数で, 式(4)で算 定する.

\section{b）損傷レベル $2 \cdot 3$ 限界点}

釣合軸力を超える軸方向圧縮力が作用する場合には， 損傷レベル 2 および 3 の限界点を統合して損傷レベル 2 ・3 限界点とする. これは, 高い軸方向圧縮力が作用 する場合には, かぶりコンクリートが大幅に剥落すると 同時に軸方向鉄筋の座屈が進展し，すぐに軸方向鉄筋の 大変形や座屈が生じて急激な荷重低下が生じるため, 損 傷レベル 2 と 3 は区別しないこととした. 損傷レベル 2 ・3 限界点は, 以下に示すとおり算定することとする. まず, 荷重は, コンクリートの最外縁圧縮ひずみが $\varepsilon^{\prime}{ }^{\prime}=0.0035$ となるときの荷重とする.

また, 損傷レベル $2 \cdot 3$ 限界点の変位 $\delta_{c n}$ は, く体の 曲げ変形による変位 $\delta_{c n 0}$ と, フーチングからの軸方向 鉄筋の抜出しによる回転変位 $\delta_{c n l}$ の和として算定する. ここで, く体の曲げ変形による変位 $\delta_{c n 0}$ は, さらに塑 性ヒンジ部の曲げ変形による変位 $\delta_{c n p}$ と塑性ヒンジ部 以外の曲げ変形による変位 $\delta_{c n b}$ に分けて算定寸る.

$$
\delta_{c n}=\delta_{c n 0}+\delta_{c n l}=\delta_{c n b}+\delta_{c n p}+\delta_{c n l}
$$

ここに, $\delta_{c n}:$ 損傷レベル $2 \cdot 3$ 限界点の変位

$\delta_{c n 0}$ : 損傷レベル $2 \cdot 3$ 限界点のく体変形に よる変位 $\left(=\delta_{c n b}+\delta_{c n p}\right)$

$\delta_{c n b}$ : 損傷レベル $2 \cdot 3$ 限界点のく体変形の うち, 塑性ヒンジ部以外の曲げ変形によ る変位. 部材を材軸方向に分割し, それ ぞれの断面の曲率を 2 階積分することに 
より算定する.

$\delta_{c n l}:$ 損傷レベル $2 \cdot 3$ 限界点のフーチング内 からの軸方向鉄筋の拢出による回転変位

$$
\delta_{c n I}=\delta_{c u l}
$$

$\delta_{c n p}:$ 損傷レベル $2 \cdot 3$ 限界点のく体変形のう ち, 塑性ヒンジ部の曲げ変形による変位

$$
\delta_{c n p}=\theta_{p c n} \cdot\left(L_{a}-L_{p} / 2\right)
$$

ここに, $\theta_{p c n}$ : 損傷レベル $2 \cdot 3$ 限界点の塑性ヒンジ 回転角で, 式(30)で算定する.

$L_{p}$ : 等価塑性ヒンジ長で式(8)で算定する.

$$
\theta_{p c n}=\left(0.021 k_{\mathrm{w} 0} \cdot p_{\mathrm{w}}+0.013\right) / 0.78
$$

ただし, $0.021 k_{\mathrm{w} 0} \cdot p_{\mathrm{w}}+0.013 \leqq 0.04$

ここに, $p_{\mathrm{w}}:$ 帯鉄筋比(\%)

$k_{\mathrm{w} 0}$ : 帯鉄筋の強度を考慮する俰数

図一21 (d) より, 各限界点の計算値は, 実験值を安全 側に評価している.

\section{7. 結論}

場所打ち鉄筋コンクリート杭部材を模擬した供試体を 用いた実験結果をもとに，部材の損傷レベルの設定と， 部材の各損傷レベル限界点の荷重および変位の算定方法 について検討した結果, 以下の結論が得られた.

(1) 場所打ちコンクリート杭の施工を模擬して, 供試 体のコンクリートを水中および泥水中で打設し， 締め固めを行わないで製作し載荷実験を行った。 通常の気中施工で締め固めを行った場合と比べて, 鉄筋とコンクリートの付着性状に若干の違いは認 められるものの, 荷重変位関係は施工条件による 顕著な差は見られなかった.

（2） 円形断面の場合，最大耐力以降，降伏耐力に至る までの水平荷重の低下は，帯鉄筋比が大きいほど 低下割合が緩やかになることが明らかになった。 また, 荷重低下割合は, 繰返し回数に影響を受け ることが明らかになった。

（3）鉄筋コンクリート杭部材の復旧性を照査するため の損傷レベルについて，すでに提案されている柱 部材の場合と同様に, 補修の難易度を考慮して損 傷レベルを 4 段階で考慮し，想定される補修工法 のイメージと対応させて評価することの提案を行 った.

（4）各損傷レベル限界点の荷重および変位の算定方法 を，柱部材の算定方法をもとに，杭部材への適用
方法について検討を行い, 比較的低い軸方向力が 作用し曲け破壊形態を有する実験結果に対して, 以下に示す方法で算定できることを明らかにした.

a) 損傷レベル 1 限界点の変位は，曲率積分によ り算定したく体変形と鉄筋抜出しによる回転 変位の和として，式(1)で妥当に評価できる.

b) 損傷レベル 2 限界点の変位は, 塑性ヒンジ部 の曲げ変形, 塑性ヒンジ部以外の曲げ変形お よび鉄筋抜出しによる回転変位の和として, 式(6)で妥当に評価できる，このとき，塑性ヒ ンジ部の曲げ変形は，帯鉄筋比等をパラメー タとする塑性ヒンジ回転角の実験式を用いて 推定できる.

c) 損傷レベル 3 限界点の変位は，損傷レベル 2 限界点と同様の考え方で算定できる．このと き，塑性ヒンジ部の曲げ変形は，塑性ヒンジ 回転角の損傷レベル 2 からの增分を考慮する ことにより, 式(18)で推定できる.

d) 上記の各損傷レベルの限界変位の推定方法の 実験に用いた供試体の各パラメータの範囲か ら得られる適用範囲は, 以下のとおりである.

軸方向鉄筋比（\%) : 1.01 2.02

帯鉄筋比 $\quad(\%): 0.19 \sim 0.38$

軸力比 $\left(\sigma_{0} / f_{c}^{\prime}\right) \quad: 0 \sim 0.11$

（5）上記損傷レベル限界点の推定方法を，上記適用範 囲外の軸力範囲への適用性について検討した。軸 力比 $\left(\sigma_{0} / f_{c}^{\prime}\right)$ がー0.14 0.42の範囲の実験につい て，上記推定方法の適用性を検討したところ，以 下の知見が得られた。

a) 釣合軸力を超える高い軸方向圧縮力が作用す る場合, 損傷レベル 1 限界点の変位は式(24)で 算定できる．また，損傷レベル 2 以降の損傷 の進展が急激であるため, 損傷レベル 2 およ び3の限界点を統合して限界点の変位を式(27) で推定できる.

b) 本実験において軸方向引張力が作用する場合， 損傷レベル 1 限界点および損傷レベル 2 限界 点の変位は, 式(1)および式(6)を用いて推定で きた. また，損傷レベル 3 以降の損傷の進展 はなかったため, 損傷レベル 3 限界点は設け る必要がないと考えられる.

c) 変動軸力が作用する場合, 各損傷レベルの限 界変位は，上記の算定方法を用いて妥当に評 価できる.

謝辞 : 本論文で用いた実験の一部は，日本鉄道建設公団 からの委託により実施されたものです. 関倸者の皆様に 謝意を表します。 


\section{参考文献}

1）たとえば土木学会 : コンクリート標準示方書・耐震設計 編 [平成8年制定 $], 1996.7$.

2）たとえば土木学会 : 阪神淡路大震災被害分析と勒性率評 価式，コンクリート技術シリーズ12，pp.52〜 53，1996.7.

3）渡邊忠朋, 谷村幸裕, 瀧口将志, 佐藤勉; 鉄筋コンクリ 一下部材の損傷状況を考慮した変形性能算定手法, 土木 学会論文集, 第683号 /V-52, pp.31 45, 2001.8.

4) 谷口善則, 渡邊忠朋, 村田修 : 場所打ちコンクリート強 度の実態調查，コンクリート工学，vol32，№.4，pp22～ 30,1994.4.

5) 渡邊忠朋，村田修，谷口善則：場所打ちRC杭の強度に関 する実験的研究，コンクリート工学年次論文報告集, vol.15, No.1, pp.477 482, 1993.

6) 白都滋，稲村利男，田村昌仁，勅使河原正臣：実大場所 打ちRC杭の実験的研究, コンクリート工学年次論文報告 集, vol.20, No.3, pp.895 900, 1998.

7) 長江拓也, 香取慶一, 林静雄 : 場所打ちコンクリート杭 への高強度せん断補強筋の適用に関する考察，コンクリ 一下工学年次論文報告集，vol.21，No.3，pp.403～408，1999.

8) 是永健好, 勝倉靖, 小室努, 川端一三：異形 $\mathrm{PC}$ 鋼棒で横 補強したRC杭の大型模型実験，コンクリート工学年次論 文報告集，vol.21，№.3，pp.475～480，1999.

9）新井元植, 吉田誠, 山本俊彦, 山田和夫 : 場所打ち鉄筋 コンクリート杭の曲げせん断挙動に関する実験的研究, コンクリート工学年次論文報告集, vol22, No.3, pp.667〜 $672,2000$.

10）㴰口将志, 渡邊忠朋 : 場所打ちRC杭の変形性能に関する 実験的研究，コンクリート工学年次論文報告集, vol.19, No.2, pp.801 806, 1997.

11) 菅原篤, 伊藤真, 戸塚信弥 : 高強度せん断補強鉄筋を用
いた場所打ちコンクリート杭の水平載荷試験（その 1 : 一定軸力での試験結果)，土木学会第53回年次学術講演 会概要集第1部B, pp.198〜 199, 1998.10.

12）棚村史郎, 近藤政弘, 青木一二三, 戸塚信弥 : 高強度せ ん断補強鉄筋を用いた場所打ちコンクリート杭の水平載 荷試験（その 2 : 変動軸力での試験結果）, 土木学会第 53 回年次学術講演会概要集第1部B, pp.200 201，1998.10.

13) 渡邊忠朋, 瀧口将志, 佐藤勉 : 場所打ちRC杭の変形性能 評価, コンクリート工学年次論文報告集, vol20, №.3, pp.1051〜1056, 1998.

14）土木学会 : コンクリート標準示方書 設計編 [平成8年制 定] , 1996.

15）島弘，周礼良，岡村甫 : 異形鉄筋の鉄筋降伏後における 付着特性, 土木学会論文集, 第378号 $/ \mathrm{r}-6, \mathrm{pp} .213-220$, 1987.2.

16) Mattock,A.H. : Discussion of "Rotation Capacity of Reinforced Concrete Beams" by W.G.Corley, Journal of Structual Division ASCE ,vol.93.ST2,pp.519-522 April.1967.

17) 田中寿志, 瀧口将志 : RC柱の変形性能と損傷レベルに関 する実験的研究，コンクリート工学年次論文報告集， vol.20, No.3, pp.1045 1050, 1998.6 .

18）財団法人鉄道総合技術研究所編：鉄道構造物等設計標 準・同解説（コンクリート構造物），丸善，1992.10.

(2001.11. 20 受付)

\title{
A STUDY ON EVALUATION METHOD OF DEFORMATION CAPACITY FOR CAST-IN-PLACE REINFORCED CONCRETE PILE
}

\author{
Yukihiro TANIMURA, Tadatomo WATANABE, Masayuki TAKIGUCHI \\ and Tsutomu SATO
}

\begin{abstract}
The seismic design codes for concrete structures were revised in several organizations after Hyogo-ken Nanbu earthquake. To aim at a performance based seismic design for reinforced concrete columns, we proposed deformation limit points related to damage levels taking restorability into account and a method of evaluating the deformation capacity of each limit point.

In this paper, deformation limit points of the cast-in-place reinforced concrete pile are defined and a method of evaluating the deformation capacity of each limit point in consideration of the section shape, the construction condition and the axial load is proposed based on the method for reinforced concrete columns.
\end{abstract}

